\author{
SCIREA Journal of Sociology \\ http://www.scirea.org/journal/Sociology
}

December 14, 2021

Volume 5, Issue 6, December 2021

https://doi.org/10.54647/sociology 84718

\title{
Hidden and coherent chronology of Jesus' life in the literary work of Maria Valtorta
}

\section{Liberato De Caro $^{1, *}$, Fernando La Greca ${ }^{2}$ and Emilio Matricciani ${ }^{3}$}

${ }^{1}$ Istituto di Cristallografia, Consiglio Nazionale delle Ricerche (IC-CNR), via Amendola 122/O, 70126 Bari, Italy; liberato.decaro@ic.cnr.it

2 Dipartimento di Studi Umanistici, Università degli Studi di Salerno, via Giovanni Paolo II 132, 84084 Fisciano, Italy; flagreca@unisa.it

${ }_{3}$ Dipartimento di Elettronica, Informazione e Bioingegneria, Politecnico di Milano, Piazza Leonardo da Vinci 32, 20133 Milano, Italy; emilio.matricciani@polimi.it

* Correspondence: liberato.decaro@ic.cnr.it

\begin{abstract}
:
Maria Valtorta (1897-1961) was a mystical writer active in the years of World War II. Her literary work contains a detailed life of Jesus, without any explicit dates with respect to the Julian calendar. She sets Jesus' birth (Nativity) on Kislev 25, first day of the Hebrews' feast of Hannukah, and Jesus' age at his death, on a Friday, in 1737 weeks. She writes that the Passover of the year before his death fell on Saturday. All these chronological data are unusual in mystical writings concerning Jesus' life and raise the question about their
\end{abstract}


coherence and self-consistency. We have studied these data and show that they refer to a hidden and coherent chronology. The astronomical and calendar analysis of these data allow: i) To set Jesus' crucifixion on 23 April 34, a unusual date but the only one that can harmonize Johannine and Synoptic traditions about the Last Supper; ii) To verify that the Nativity set on Kislev 25 is compatible only with the Eastern tradition, 6 January 1 AD; iii) To assess that between birth and death's dates exactly 1737 weeks have elapsed. Maria Valtorta proposes also an original story about the Star of Bethlehem: the Magi would have realized the birth of the Messiah by counting the days elapsed between some astronomical conjunctions, decoding the meaning of the numbers, so obtained, through Gematria, in close agreement with all other details of her narration.

Keywords: Maria Valtorta, Jesus of Nazareth, Nativity Day, Hanukkah, Herod the Great, Magi, Star of Bethlehem, Gematria, Last Supper. Crucifixion.

\section{The literary work of Maria Valtorta}

The history of Christianity has always been characterized by mystics, persons who claim having direct talks with Jesus, visions of his life, described in literary works. In principle, any scientific assessment of the details contained in these writings would seem impossible but, in some recent works (Matricciani and De Caro 2017, 2018, 2020; De Caro et al. 2020; De Caro et al. 2021a), a series of studies have been carried out on the writings of an Italian mystic of the 20th century, Maria Valtorta (1897-1961; MV).

Her writings on Jesus' life contain a large amount of historical, biblical, geographical, archaeological, astronomical and meteorological information, hardly attributable to her skills because MV received an education certainly higher than the average of her times, but surely not enough to justify what emerges from a careful analysis of her writings. Indeed, her very large literary work is unique because has allowed, for the first time, a scientific approach in studying alleged mystical writings. 
In (Matricciani and De Caro 2017) we have shown that MV, in her narration of Jesus' life (Valtorta 2001e), has also recorded the occurrence of rain, so that the number of rainy days reported can be compared to the current meteorological data, supposing random observations and no important changes in the frequency of rainy days in the last 2000 years. Unexpectedly, both the annual and monthly averages of rainy days agree with those calculated from the data of the Israel Meteorological Service.

In (Matricciani and De Caro 2018) we assessed mathematical similarities and differences in her writings, because she claims that most of them are due to mystical visions. We have used mathematical and statistical tools developed for specifically studying deep linguistic aspects of texts (Matricciani 2019). The general trend indicates that texts explicitly attributable to MV (e.g., her Autobiography) differ significantly from the texts attributable - as she claims- to the alleged characters of Jesus and Mary, or to her Guardian angel. Mathematically, they seem to have been written by different authors. The comparison with the Italian literature is very striking. A single author, namely MV, seems to be able to write texts so diverse as to cover the entire mathematical range (suitably defined) of the Italian literature spanning seven centuries.

In (Matricciani and De Caro 2018) we have studied Jesus Christ's speeches contained in The Gospel as revealed to me (Valtorta 2001e), MV's main literary work, to assess: i) mathematical similarities and differences of the speeches delivered to diverse audiences; ii) duration of the speeches, delivered in different occasions; iii) structure of the speeches, evaluated through deep-language statistics; iv) whether the setting of the speeches is realistic. By converting sequences of words into intervals, through a suitable reading/speaking speed, the speeches' durations were found to be realistic. The setting of the speeches has allowed to assess the likelihood of the places and occasions for delivering them: the speeches are fully realistic in whatever mathematical parameter, or setting, we have studied.

MV also describes apostle Peter's first burial site, which - she writes- was not on the Vatican Hill. In (De Caro et al. 2020) the analysis of these texts, checked against the archeology of Rome of the I century and its catacombs, has allowed us to locate Peter's alleged first burial 
site in a hypogeum discovered in 1864 but not yet fully explored, near the beginning of Via Nomentana, in Rome. The probability that MV, by chance, invented the data that lead to this particular site, is very small and reinforces the conclusion, already reached with archeology, that casualness is very doubtful.

MV also describes apostle Peter's last burial site which, she writes, was in the catacombs of SS Marcellino and Pietro, in Via Casilina, in the district of Rome known as Tor Pignattara (De Caro et al. 2021). Besides some striking archeological finds on Peter's memory, already discovered near a particular cubicle in these catacombs, a geometrical and mathematical study of the unusual architectonic characteristics of the Basilica and St. Helen's Mausoleum built in the catacombs area, shows that these buildings were part of a single architectonic plan, very likely designed for coding data useful to locate Peter's burial site unambiguously, in the area of the cubicle mentioned, a result to be verified by archeologists.

Given the above results, in the present paper we report the findings of a new study of her literary work directed to date birth and death of Jesus. Indeed, in her Jesus' life she does not report any date in terms of Julian calendar. Nevertheless, her literary work is full of chronological elements.

According to MV Jesus was born on Kislev 25 (Valtorta 2001a, p. 458, Valtorta 2001b, p. 375). This day was the first day of the Feast of Temple Dedication- called the Feast of lights by Josephus (I century AD - Anno Domini-, JA XII,7), and known as Encenie in Greek, Hanukkah in Hebrew - a feast introduced in the II century BC (Before Christ).

She explicitly states that in the year before his death, the Passover Eve-14 of Nisan of the lunar-solar calendar - was a Friday (Valtorta 2001e, chapters 372-375) and that Passover fell on the Sabbath (Valtorta 2001e, chap. 378). The crucifixion is set on a Friday, in agreement with the four canonical Gospels (Matthew - Mt-; Mark - Mk-; Luke - Lk-; John - Jh).

MV also writes (Valtorta, 1993) that in the day of his death Jesus aged 1737 weeks exactly, a curious unit of time. Another curious datum concerns the Star di Bethlehem - which allegedly led the Magi to Jesus (Mt 2,1) - described (Valtorta 2001a, p. 207-208) as a 
supernatural event, not astronomical, which, however, the Magi interpreted as the birth of the Messiah, by relating it to real astronomical observations occurred just before, thanks to their astronomical knowledge (Valtorta 2001a, p. 211). The West Tradition sets Jesus's birth on December 25, 1 BC, the East Tradition sets it on January 6, 1 AD. Therefore, it is unexpected that MV sets it on Kislev 25. Now, after the previous findings - discussed recently (Matricciani and De Caro 2017, 2018, 2020; De Caro et al. 2020; De Caro et al. 2021a) - we challenge the above chronological elements to be consistent with each other. In particular, the aim of our study is to assess whether: i) the narration of Jesus' birth and death dates are chronologically coherent; ii) Kislev 25 could coincides with January 6 of the East Tradition or December 25 of the West Tradition; iii) a Crucifixion date can be determined and be compatible with an age of 1737 weeks; iv) the narration of the Magi and Star of Bethlehem is, from a chronological point of view, coherent with Jesus' birth so determined.

In Section 2 we verify whether the traditional Nativity Day December 25 (Western tradition) or January 6 (Eastern tradition) is related to the beginning of the Hebrew feast of Hanukkah (Kislev 25) in one of the years in which Jesus' birth can be set, namely in the years from 6 BC to $1 \mathrm{AD}$. In Section 3 we study the historical background of the traditional Nativity Day, by investigating the implicit chronological constraints contained in the Gospels for verifying whether they support the historicity of Jesus' birth set at the beginning of the winter (end of Kislev). In Section 4 we summarize the data concerning the Star di Bethlehem (Mt, 2) described by MV. In section 5 we study the astronomical conjunctions just before the beginning of the Christian Era, a possible decoding of their time series in terms of birth of a king, according to MV's narration. In section 6 we propose a reconstruction of why and when the Magi very likely moved towards Palestine, based MV's writings. In Section 7 we summarize all possible dates of Jesus' death established after astronomical and calendar studies, to verify if there were two consecutive years when the Passover fell on Saturday, as indicated by MV for the two last years of Jesus' life. We will also discuss which of the Crucifixion's dates - allowed astronomically- better harmonizes the different traditions, John's or Synoptics', about the Last Supper of Jesus. In Section 8, by correlating the date of 
Crucifixion with the date of birth set on Kislev 25, we establish the age of Jesus when he died, in relation with the number of weeks 1737, indicated by MV. The results of this analysis allow to verify whether MV's literary work contains a well-defined, hidden and coherent chronological background on Jesus' life (Section 9), expressed through unusual calendar elements for a modern writer, such as the Nativity set on Kislev 25 and the Jesus' age of 1737 weeks at his death.

\section{Relationships between Kislev 25 and the Nativity Day of the tradition}

MV (2001a, p. 458; 2001b) writes that Jesus was born on Kislev 25, an unexpected datum, since it would be reasonable to find indicated either December 25 or January 6, according to the main traditions of Christianity. Now, to verify whether Kislev 25 coincides with December 25 or January 6 it is necessary to convert dates from the luni-solar calendar to the Julian calendar. However, this conversion is not straight, but it requires to address several arguments: the presence of embolismic years (years of 13 lunar months) in the luni-solar calendar and leap years in the Julian calendar; the beginning of months in the luni-solar calendar; the beginning of the Feast of Temple Dedication. These topics are discussed in the following sub-sections.

\subsection{Embolismic years in the luni-solar calendar}

In the Jewish luni-solar calendar of 2000 years ago the beginning of a month was fixed by direct observation of the first crescent moon, not by looking at a pre-compiled table. The year started with the month of Nisan, at the first new moon after the vernal equinox, which 2000 years ago occurred on March 23 of the Julian calendar. In some years a month was added at the end of the year for realigning astronomically the calendar with the seasons because a lunar month lasts 29.53 days and years are of 12 months of 29 or 30 days, never 31 . Now, $12 \times$ $29.5=354$ days, which is about 11 days less than 365.24 days of the solar year. About every

3 years, $3 \times 11=33$ days, therefore a thirteen (intercalary) month was added, although not known when. This extra month was termed second month of Adar, Adar II, as Adar is the last 
month of the year, and its insertion was decided by the Sanhedrin (Finegan 1998, p. 38) according to the following rules: "The rabbis taught, it is stated, that "a year may be intercalated on three grounds: on account of the premature state of the corn crops; or that of the fruit trees; or on account of the lateness of the tequfah (season). Any two of these reasons can justify intercalation, but not one alone". (...) The tequfah of Nisan... began at the vernal equinox when the sun enters the constellation of Aries». Therefore, if the ears of corn were not ripe, the liturgy planned on Nisan 16 (Leviticus 23,10-11) - the offering to the Temple of the first harvested ears of barley or wheat - could not occur and Passover was delayed by introducing the second month of Adar. Also, Josephus (I century AD; AJ III. 248) recalls the same rules on how to determine the date of Passover since Moses established it.

\subsection{Leap years in the Julian calendar}

In the first decades of introduction of the Julian calendar, more leap years than necessary were inserted in the calendar. We don't know what the leap years' sequence was. A very likely hypothesis is the following: since $45 \mathrm{BC}$, first leap year, to $9 \mathrm{BC}$, leap years - made of 366 days instead of 365 -were inserted every 3 years instead of 4 because of a wrong interpretation of the rule to insert 1 leap year after 3 normal years. Caesar Augustus (Fedalto 2012) corrected the error, probably in $8 \mathrm{BC}$, by ordering not to introduce leap years for 15 years, therefore only after $8 \mathrm{AD}$ the days in the Julian calendar were correctly calculated, with leap years every 4 and the first correct leap year of the Christian era probably was 8 AD. For example, $5 \mathrm{BC}$ should have been a leap year - but was not so - to reduce the delay from 3 to 2 days; similarly, $1 \mathrm{BC}$ should have been a leap year to reduce the delay from 2 to 1 day, but it was not so.

When a date of the Julian calendar is calculated in the years just before and after Christ, with modern astronomical software - which give correct dates assuming correct series of leap years -, we must consider the error in days to determine the (wrong) date of the Julian calendar of those years, because the actual date is shifted few days compared to the correct date. Indeed, when dates must be converted in a different calendar, it should be considered that the Julian calendar of that time is shifted by 1 or more days with respect to the correct 
calendar date, due to the excess of leap days introduced. Only in this way, for the years at the turn of the beginning of the Christian era, we can verify, with one-day precision, whether there is a relationship between a specific date of the Julian calendar and a specific date of the Jewish calendar.

\subsection{Beginning of the months in the luni-solar calendar}

The beginning of the lunar month was determined by direct observation of the Moon. To convert dates from the Jewish luni-solar calendar to the Julian calendar, we must assume a criterion of visibility of the crescent moon. The Sanhedrin declared (Finegan 1998, p. 37) the beginning of a new month after two observers, dedicated to observing the moon, agreed to having seen a small crescent moon and answered, in agreement with each other, to some ritual questions.

Today, one of the most accepted criterions, among several proposed by scholars (Doggett et al. 1994), states that, to be visible with naked eyes, the lunar disc must be illuminated for at least $2 \%$. However, even if so, the moon might not be seen because of clouds. Now, as months in the luni-solar calendar could be only of 29 or 30 days - never 31 -, it was common practice, in this case, to delay the beginning of the month by 1 day. Therefore, to convert dates, in case of delay, we have considered an illuminated fraction $2.5 \%$ at maximum, because larger values very likely correspond to a month, just finished, already of 30 days. Moreover, in particularly favorable meteorological conditions, such as a clear sky, the moon could have been visible with fractions smaller than $2 \%$, but reasonably never smaller than $1 \%$. For these reasons, it is prudent to convert a date from the luni-solar calendar to the Julian calendar by associating a small interval to it. In this way, the calendar reconstruction, based on astronomical analysis, does not depend on the criterion of visibility of the crescent moon adopted.

\subsection{The beginning of the Feast of Temple Dedication in the Julian calendar}

After the important issues on converting dates between the two calendars, we summarize the results obtained in the conversion (Chevalley 2006) in Table 1, which reports the beginning of 
the month of Kislev and the beginning of the Feast of Temple Dedication (25 Kislev) for the years from $6 \mathrm{BC}$ to $1 \mathrm{AD}$.

Because it is not known which year was embolismic, we report also dates delayed by 1 lunar month when Nisan 15 (Passover) fell too near March 23, vernal equinox. After the studies (Parker et al 1956) on the Babylonian calendar, for which the series of embolismic years is known - they affected very much the Jewish calendar (Finegan 1998, p. 33-39) -, we have excluded the cases in which Nisan 15 would fall up less than 3 days from the vernal equinox. The dates of Kislev 1 and Kislev 25 in case of embolismic years are also reported. Besides the (correct) date of the calendar calculated today, we have also indicated the (wrong) date of the Julian calendar of the epoch, shifted few days, according to the year, because of the excessive insertion of leap years, discussed in Section 2.2.

Table 1. Beginning of the month of Kislev and the Feast of Dedication (Kislev 25) in the years from 1 AD to $6 \mathrm{BC}$, determined by the astronomical calculation of moon phases. $\mathrm{E}=$ embolismic year. In bold the dates particularly close to those of the Nativity of the Eastern tradition (January 6) and Western (December 25). The first day of Nisan started the new year of the Jewish lunar-solar calendar of 2000 years ago. In round brackets the dates of the current calendar of that time, influenced by the incorrect calculation of leap days.

\begin{tabular}{|c|c|c|c|}
\hline Year & 1 Nisan & $\begin{array}{c}\text { Interval (days) for } 1 \\
\text { Kislev }\end{array}$ & Interval (days) for $25 \mathrm{Kislev}$ \\
\hline $1 \mathrm{AD}$ & $\begin{array}{l}\text { 15-16 March } \\
\text { (14-15 March) }\end{array}$ & $\begin{array}{l}\text { 5-7 November } \\
\text { (4-6 November) }\end{array}$ & $\begin{array}{c}29 \text { November-1 December } \\
\quad(28-30 \text { November })\end{array}$ \\
\hline $1 A D(E)$ & $\begin{array}{l}\text { 13-14 April } \\
\text { (12-13 April) }\end{array}$ & $\begin{array}{l}\text { 5-7 December } \\
\text { (4-6 December) }\end{array}$ & $\begin{array}{l}\text { 29-31 December } \\
\text { (28-30 December) }\end{array}$ \\
\hline $1 \mathrm{BC}$ & $\begin{array}{l}\text { 25-26 March } \\
\text { (24-25 March) }\end{array}$ & $\begin{array}{l}\text { 16-18 November } \\
\text { (15-17 November) }\end{array}$ & $\begin{array}{l}\text { 10-12 December } \\
\text { (9-11 December) }\end{array}$ \\
\hline $1 B C(E)$ & $\begin{array}{l}\text { 24-25 April } \\
\text { (23-24 April) }\end{array}$ & $\begin{array}{l}\text { 15-17 December } \\
\text { (14-16 December) }\end{array}$ & $\begin{array}{l}\text { 8-10 January } 1 \text { AD } \\
\text { (7-9 January } 1 \text { AD) }\end{array}$ \\
\hline $2 \mathrm{BC}$ & 6-7 April & 27-29 November & 21-23 December \\
\hline
\end{tabular}




\begin{tabular}{|c|c|c|c|}
\hline & (4-5 April) & (25-27 November) & (19-21 December) \\
\hline $3 \mathrm{BC}$ & $\begin{array}{l}\text { 18-19 March } \\
\text { (16-17 March) }\end{array}$ & $\begin{array}{l}\text { 8-10 November } \\
\text { (6-8 November) }\end{array}$ & $\begin{array}{c}\text { 2-4 December } \\
\text { (30 November-2 December) }\end{array}$ \\
\hline $3 B C(E)$ & $\begin{array}{l}\text { 16-17 April } \\
(14-15 \text { April })\end{array}$ & $\begin{array}{l}\text { 9-10 December } \\
\text { (7-8 December) }\end{array}$ & $\begin{array}{c}2-3 \text { January } 2 B C \\
\text { (31 December-1 January } 2 B C\end{array}$ \\
\hline $4 \mathrm{BC}$ & $\begin{array}{l}\text { 28-29 March } \\
\text { (26-27 March) }\end{array}$ & $\begin{array}{l}\text { 20-21 November } \\
\text { (18-19 November) }\end{array}$ & $\begin{array}{l}\text { 14-15 December } \\
\text { (12-13 December) }\end{array}$ \\
\hline $5 \mathrm{BC}(\mathrm{E})$ & $\begin{array}{l}\text { 8-9 April } \\
\text { (6-7 April) }\end{array}$ & $\begin{array}{l}\text { 29-31 November } \\
\text { (27-29 November) }\end{array}$ & $\begin{array}{l}\text { 23-25 December } \\
\text { (21-23 December) }\end{array}$ \\
\hline $6 \mathrm{BC}$ & $\begin{array}{l}\text { 21-22 March } \\
\text { (18-19 March) }\end{array}$ & $\begin{array}{l}\text { 12-13 November } \\
\text { (9-10 November) }\end{array}$ & $\begin{array}{l}\text { 6-7 December } \\
\text { (3-4 December }\end{array}$ \\
\hline $6 B C(E)$ & $\begin{array}{l}\text { 20-21 April } \\
\text { (17-18 April) }\end{array}$ & $\begin{array}{l}\text { 11-13 December } \\
\text { (8-10 December) }\end{array}$ & $\begin{array}{l}\text { 4-6 January } 5 \text { BC } \\
(1-3 \text { January } 5 \text { BC) }\end{array}$ \\
\hline
\end{tabular}

The dates concerning Nisan 1 are reported by indicating 2 days of the Julian calendar because the new day started after sunset and finished at the beginning of the sunset of next day. According to the Gospels, Jesus was born in the night, therefore after sunset of Kislev 24, at the first hours of Kislev 25. To the dates of Kislev, we have associated an interval of possible days in the Julian calendar, because moon visibility depends on the criterion of visibility of the fraction of surface illuminated. Making it ranging from $1 \%$ to $2.5 \%$ we get the intervals reported in Table 1. The most interesting date is the lower value of the interval, corresponding to the transition from Kislev 24 to Kislev 25. In the rightmost column we have evidenced the dates of Kislev 25 nearest to the Nativity Day of West and East traditions. In 1 AD, they are January 7-9 with its lower limit just 1 day after the East tradition. In 5 BC the interval is December 21-23, with its upper value just 2 days smaller that December 25, West tradition. Therefore, the night of 25 Kislev is 3 days before December 25.

It is interesting to notice that in the Jewish calendar of $1 \mathrm{BC}$ (embolismic year), Kislev 25 corresponds almost exactly - 7 January 1 AD - with the Nativity Day of the East tradition, 
just at the beginning of the Christian era calculated by Dionysius Exiguus, whose correctness has been recently revalued (La Greca and De Caro 2017, 2019, 2020), also by considering the non-visibility with naked eyes of partial lunar eclipses characterized by an umbral magnitude of only about one third, such as the eclipse often associated by scholars to Herod's death in the 4 BC (De Caro et al. 2021b): for Herod's last days see Josephus, Jewish War=BJ I. 647673; II. 1-13; Jewish Antiquities = AJ XVII. 146-199. The lunar eclipse, associated to Herod's death, is specifically mentioned in $A J$ XVII. 167.

Indeed, since the XIX century, most scholars still associate to Herod's death the eclipse occurred on 13 March $4 \mathrm{BC}$, so that Dionysius Exiguus was wrong in calculating the beginning of the Christian era-by four years at least-because Herod the Great must have been alive when Jesus was born. We have solved the apparent incompatibility of the events narrated by Josephus, occurring between the eclipse of 13 March $4 \mathrm{BC}$ and a too-near Passover (12 April 4 BC), by determining another date after studying all eclipses visible from Jerusalem in near years. This analysis, supported by a novel simulation of naked-eye visibility of partial lunar eclipses (De Caro et al. 2021b), has shown that the most eligible eclipse associable to Herod's death occurred in the night of 8-9 November 2 AD. Therefore, Herod the Great should be died in the first month of $3 \mathrm{AD}$ and, very likely, Dionysius Exiguus' calculus about the beginning of the Christian Era was correct.

In this contest, it is remarkable what we have verified in this section: $1 \mathrm{AD}$ is the only year, among those in which we can put Jesus' birth, in which Kislev 25 can coincide with one of the dates of Nativity of the Christian tradition, the Eastern one. Moreover, this happens just in the year calculated of Dionysius Exiguus, since between West (25 December 1 BC) and East tradition (6 January 1 AD) there are only 2 weeks. In other words, the unusual chronological element of Kislev 25, reported in the MV's literary works, seems to refer, implicitly, just to one of the Nativity traditions, the East one, and just to the beginning of Christian Era calculated by Dionysius Exiguus. 
Kislev 25 usually falls at the beginning of the winter, such as Nativity traditional dates. In the next Section we discuss some possible historical backgrounds and chronological implications of the traditional Jesus' birth set at the beginning of the winter.

\section{Other chronological implications of the Jesus' birth set on Kislev 25}

Both West and East traditions set the birth of Jesus at the beginning of the winter, within a difference of two weeks, December 25 or January 6 . What is the origin of this information? Has it some historical background? These are the open questions to which scholars aim to answer (Nothaf 2021a). However, it is worth noting that this information could be also partially deduced directly from the canonical Gospels, as we show now.

According to Luke, Elizabeth - Mary's relative and wife of the priest Zechariah - was pregnant in the sixth month at the time of the Annunciation to Mary. Now, according to the Mosaic Law, in a year three pilgrimages to Jerusalem were required during three feasts: the first was at Passover (15-22 Nisan, first month of the luni-solar calendar), the second was at Pentecost (50 days after Passover) and the third was at the Tabernacles (15-22 Tishri, seventh month). Therefore, the maximum period elapsed between two successive pilgrimages was 6 months - from the Tabernacles to the following Passover - or 7 months in case of an embolismic year. Luke notes that Joseph and Mary strictly followed the Mosaic Law (Lk $2,41)$; therefore, it is plausible to assume that if there had been a pilgrimage between the annunciation to Zechariah - Elizabeth would give birth to a son - and the annunciation to Mary, Joseph - Mary's husband - would have been in Jerusalem and would have already heard from Zechariah, or from other family members, about the unexpected pregnancy of his wife Elizabeth, an aged woman.

Now, according to Luke, at the time of the Annunciation, Mary did not know Elizabeth was pregnant; therefore, at least in the previous 5 months there had been no pilgrimages, because Elizabeth was already in the sixth month of pregnancy. As the intervals between Passover and Pentecost, and between Pentecost and the Tabernacles are less than 5 months, it follows that 
the Annunciation occurred between the Tabernacles of the previous year and Passover of the following year, separated by at least 6 months, and necessarily very near the Passover. The liturgical year started at Passover, always at the vernal first full moon, usually at the end of March or beginning of April. Therefore, if we add 9 months of a pregnancy we end up to the end of December or beginning of January. Consequently, the Nativity Day should have occurred in the interval defined by West and East traditions (beginning of the winter).

Let us discuss this issue with greater details. If we subtract 9 months from Kislev 25, the date of Annunciation occurs in the month of Adar, or Adar II in case of embolismic year, i.e., at the end of the previous year of the luni-solar calendar. The annunciation to Zechariah takes place in the Temple. If we subtract 5 or 6 months respectively to Adar or to Adar II, Zechariah should have been serving during the Feast of Tabernacles (15-22 di Tishri), or during another service turn near this feast, but not during Yom Kippur because in its liturgy only the high priest could access the most sacred part of the Temple - accessible to all other priests in the rest of the year -, and Zechariah was not the high priest. Moreover, Luke clarifies that at the end of his turn, Zechariah went home (Luke 1,23); therefore, his service lasted several days. Very likely, he returned home after the Tabernacles, at the end of Tishri, seventh month of the ancient Jewish calendar. Therefore, the first month of Elisabeth's pregnancy should have been the eighth month of the luni-solar calendar so that the sixth month of pregnancy coincides with the end of the year or beginning of the next. Now, since $7+6=13$, it must have been the month Adar II or Nisan. If we consider this constraint, under the hypothesis that Jesus was born on Kislev 25, ninth month, we must exclude that the Annunciation occurred in the month of Nisan - first month of the calendar- because $9-1=$

8 months not 9, i. e. the duration of the pregnancy, therefore, we must conclude that Annunciation occurred necessarily at the end of a year of 13 months, a year with a second Adar.

In Table 1, whose dates have been calculated under the hypothesis that Jesus was born on Kislev 25, the year $1 \mathrm{BC}$ might have been embolismic, and the beginning of the Feast of Temple Dedication would have fallen very near 6 January 1 AD, Nativity Day of the East 
tradition. On the contrary, in the year $5 \mathrm{BC}$ when the feast falls near December 25, Nativity Day of the West tradition, it is not possible to introduce a month Adar II because in that year the crescent moon was already visible between April 8 and 9, and a thirteen month would have implied a month of Nisan extended to June, full summer.

In the year $2 \mathrm{BC}$, the Feast of Temple Dedication fell in October, with Tishri 15 corresponding to October 14 or 15 . This can be established also from Table 1. Consequently, the conception of John the Baptist should be placed in the third decade of October so that in April $1 \mathrm{BC}$, the time of the Annunciation, Elisabeth was at the sixth month of pregnancy, as recalled by Luke and, after 9 months, at the beginning of January, Jesus was born.

These calculations might have been at the base of the efforts of early Christians to establish the Nativity Day. Indeed, with this respect it should be noted that for some authors the Nativity Day of the Christian tradition could be based on evidence from chronological and historical backgrounds and speculations (Roll 1995). In particular, after the studies of Duchesne (1889) and Engberding (1952), Talley (1991) proposed that December 25 was calculated from the day of Jesus's Passion, whose memorial dates in the Julian calendar had already been established in the late II or early III centuries. According to this calculation Jesus died after an integer number of years, therefore early Christian chronographers could have established a chronological parallelism between his conception (i.e., the Annunciation) and his death, both assigned to March 25: indeed, adding nine months to March 25, sets his birth on December 25. Although astronomical calculations show that the Crucifixion on March 25 is not possible in the years when Pontius Pilatus was in Palestine (Nothaf 2012b) (see also Section 6), nevertheless an integer number of years from Conception to crucifixion could have a historical foundation. Indeed, if the Nativity Day is set on Kislev 25 and Jesus' death at Passover (Nisan 15), or at Passover Eve (Nisan 14), as reported by the Gospels, from the beginning of the winter (Feast of Temple Dedication) to the beginning of spring (Passover) there are about 3 months which, added to 9 months of a pregnancy, give a full year.

As a final detail, let us calculate the frequency that Kislev 25 coincides with December 25 or January 6. Figure 1 shows the histogram of the conversion of Kislev 25 to the Julian calendar, 
according to the reconstruction (Parker et al 1956) of the Babylonian calendar relative to a period of 670 years. A very similar histogram could be obtained for the Jewish luni-solar calendar, even though this latter had no prefixed beginning for months. We can notice that the counts are practically uniform (plateau). Its width is about 30 days, namely the duration of the lunar month, as expected. From March 27 to December 1 - origin of the abscissae in Figure 1- there are 249 days; from Nisan 14 to Kislev 25 there are on the average also 249 days, i.e., 8 months and 11 days; therefore, for the Babylonian calendar, Nisan 14 almost never fell before March 27.

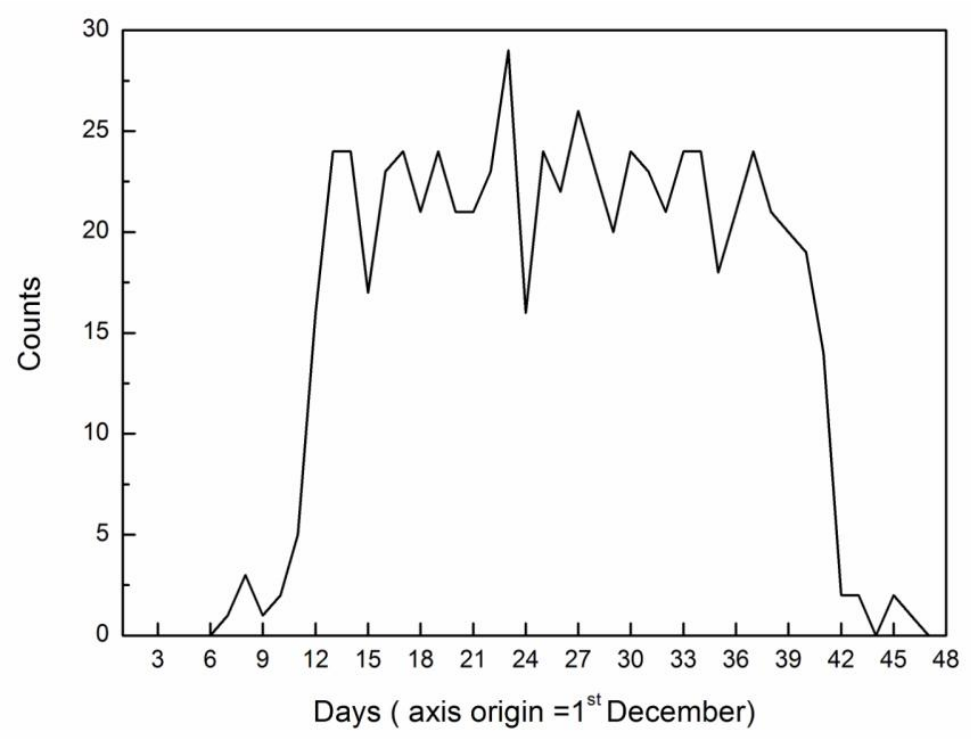

Figure 1 Frequency of Kislev 25 converted to the Julian calendar, according to the reconstruction of the Babylonian calendar relative to a period of 670 years.

The lower limit is given by the small peak after 3 days before the plateau when Nisan 15 coincides with March 25, as confirmation of what discussed till now on the results of Table 1. December 25 and January 6 fall, respectively, 24 and 36 days from the origin, therefore both are on the plateau. Consequently Kislev 25 coincides with December 25 or January 6 with the same frequency, given by (uniform distribution) $1 / 30$, that is $3.3 \%$.

Moreover, let us notice that the integer number 1737 weeks, indicated by MV (Valtorta 1993) as duration of Jesus' life, implies that if he died on Friday, he must have been born on Saturday. This is the further chronological information contained in an age expressed in weeks. Now January 8 of the year 1 AD - calculated with modern tools and corresponding to 
January 7 of the Julian calendar in use at that time because of the wrong calculation of leap years- was Saturday. The frequency that Kislev 25 falls on Saturday and on a given day of the month is $(1 / 30) \times(1 / 7)=1 / 210$, less than $0.5 \%$. It is striking that January 7 of the year 1 AD satisfies all preceding conditions. Moreover, $1 \mathrm{AD}$ is the only year in which Kislev 25 coincides, with 1-day error, with January 6, one of the two traditional dates of Nativity. The frequency $0.5 \%$ is enough small to be possible to exclude the case, implying even an historical root for this Jesus' birth dating, a point that should attract the attention of scholars, for future research.

In conclusion, MV's indication (Valtorta 2001a; Valtorta 2001b) that Jesus was born on Kislev 25, together with his age expressed in weeks (Valtorta 1993) - an information which is, at first glance, without particular interest, but implying his birth on Saturday -, it seems to have interesting historical implications, relating Gospels' chronological implicit elements, Nativity Day's traditions and the Dionysius Exiguus' calculation of the beginning of Christian Era. In the next Section we discuss what MV writes about the Magi and the Star of Bethlehem.

\section{The Magi and the Star of Bethlehem}

Since the beginning of Christianity there is a vast literature (La Greca and De Caro 2020b; (Kraabel 1982; Teres 2000; Adair 2012; Holzmeister 1942; Kepler 1614; Sinnot 1968; (Rosemberg 1972; Hughes 1976; Clark et al 1977; Cullen 1979; Mosley 1981; Firpo 1983; Paffenroth 1993; Quéré 1996; Léna 1996; Molnar 1999; Barthel et al 2015) on the Star of Bethlehem. Some first commentators (Allison 1993) of Matthew (Mt, 2) rejected the hypothesis of a natural phenomenon in favor of a divine intervention. It suffices to mention Augustine of Hippo (IV-V centuries) who condemns astrological interpretations of the Star: «we do not place the birth of any man under the fatal influence of the stars to free the will from all constraints of necessity» (Contra Faustum Manichaeum, 2.5). Others, as Origen (III century; Contra Celsum, 1.58-60), affirmed that it was a natural phenomenon, a new star like 
a comet or meteor, but of good auspicious. Until high Middle Age a miracle interpretation prevailed and only later hypothesis on a natural phenomenon re-gained credit.

The star guided the Magi to Bethlehem to adore the born Messiah (Mt, 2). The word magi is the plural of Latin magu. This term has two translations in Italian: magio (singular noun) and magi (plural), with a positive semantic meaning, like Wise men in English, and mago (singular) and maghi (plural) with a negative semantic meaning (Panaino 2012), indicating people who predict future events (divination) by means of practices forbidden by God (1 Samuel 28). The word, through Greek, is derived from Old Persian and refers to Persian priestly caste of Zoroastrianism. According to their religion, these priests paid particular attention to stars and to interpretation of astronomical phenomena for predicting future events, at that time highly regarded as a science.

As recalled in the first section, in the writings of MV we find the miracle hypothesis about the Star of Bethlehem, but also a way, by means of astronomical calculations, to deduce chronological data associated to the Magi and to their journey to Palestine, obtained by considering the cultural framework of their time. To check what she wrote, now we try to think and act as the Magi supposedly did to interpret the conjunctions of astronomical bodies.

The Magi can be considered astronomers and scientists before the modern development of astronomy and science in general, as we know and practice them since Galileo Galilei (XVII century). Indeed, astronomy was very developed 2000 years ago. Around 150-100 BC, Greek mechanical "engineers" built an amazing astronomical calculator, known as the Antikythera mechanism (Marchant 2009), capable of calculating and displaying information about astronomical phenomena concerning the planets and the Moon.

To mention just another important example, we recall the so-called Astronomical Diaries and Excerpt Texts (Hunger et al 1988-1996; Hunger et al 2001). The first covers the years 650 to $50 \mathrm{BC}$ and provides a fragmented continuous record of standardized naked-eye astronomical observations in the Middle East. The second book provides lists of positions of the sun, the 
moon and the planets computed for regular time intervals, published in astronomical cuneiform texts (Neugebauer 1955), from about 310 to 50 BC.

Besides the scientific observations, the sky was also watched for inferring future knowledge on human affairs. Indeed, the most important events of humans and history were believed to be influenced by astronomical bodies. The belief (Firpo 1983, p. 113) that in coincidence with the birth of every man a star was lighted in the sky was widespread. Diodorus Siculus (Jastrow 1908) writes (I century BC) that the Babylonians/Chaldeans called the planets "interpreters", because «they reveal (or interpret) the intention of the gods to men». Therefore, under the hypothesis that Matthew's narration is not a literary topos, but it refers to a real event - which by chance occurred concurrently with Jesus' birth and this coincidence was noted by the astronomers of 2000 year ago - it is advisable to search for astronomical events and their possible connection with the birth of Jesus.

The Magi of Mt 2 can be supposed to belong to an Eastern cast of wise men, named magi (Derovan 2007), ancient astrologers/astronomers living in the Mediterranean area and in the Middle East. They very likely were of Iranian-Chaldean origins (Firpo 1983, p. 103) or shared the widespread Babylonian knowledge on astronomy. They could predict full-moon and eclipses, retrograde motion of the five major planets (Mercury, Venus, Mars, Jupiter and Saturn) and their relative apparent approaching (conjunctions) or their conjunction with about 32 stars, referred to as the Normal Stars (Hunger et al 1988-1996; Epping 1889). These stars are very near the ecliptic - the great circle that describes the apparent path of the Sun against constellations during a year - and were reference points for measuring the apparent motion of planets (Fatoohi et al 1997-1998). At least since 600 BC to 50 BC, the astronomers used two related units for measuring planets' position (Fatoohi et al 1997-1998): the cubit, approximately equal to $2^{\circ}$, and the "finger", with $1 / 24$ cubit $\sim 0.09^{\circ}$. These units were sufficiently small to determine the exact day of the minimum angular distance between planets and the Normal Stars (conjunctions), even considering the slow apparent motion of Jupiter and Saturn (Fatoohi et al 1997-1998) with daily motion from $0.05^{\circ}$ to $0.1^{\circ}$. In few cases the daily angular variations of relative distances are smaller than the angular resolution 
of night vision with naked eyes. Therefore, the prediction of the believed influence of astronomical bodies on human events was based on long observations (Fatoohi et al 19971998) and collections of accurate and systematic data on the motion of the planets.

Now, within this historic framework of astronomical knowledge, following what MV wrote, we base our analysis of her writings on the following hypotheses: (a) the Magi were aware of the Jewish waiting of the Messiah, because many Jews lived outside Palestine; (b) the Magi wished to verify, on site, what they had deduced from astronomical observations, namely the birth of a king; therefore, they moved towards the only reign (Firpo 1983) of the Syria-Phoenicia area, namely the Reign of Judah.

These are also the hypotheses assumed by astronomers since Kepler (1614). As evidenced by Brown (1999), it is useful to try to find a natural explanation to the Star of Bethlehem, because the first Christians, and Matthew himself, might have interpreted only a posteriori a precise astronomical phenomenon - occurred concurrently with Jesus' birth -, as a sign of the birth of the Messiah. This coincidence might have been noted by eyewitnesses. In other words, the reconstruction of these astronomical events might date the birth of Jesus.

One of the important astronomical phenomena, already mentioned in tablets of Chaldean and Babylonian astronomers (Hunger et al 1988-1996; Hunger et al 2001), is the conjunction of two or more celestial bodies (two planets, a planet and a star, etc.), occurring when they seem to be very near each other. Of course, it is only a perspective effect, due to the huge distances involved.

Already in the VIII century, the Jewish astronomer/astrologer Masha'allah (Kennedy et al 1971) suggested this interpretation of the Star of Bethlehem, later re-proposed many times. Kepler (1614, p. 96-97) hypothesized that it might have been the conjunction of Jupiter, Saturn and Mars, occurred between 7 and 6 BC, therefore fixing Jesus' birth in 5 BC. Hughes $(1976$; 1979) proposed 15 September 7 BC when Jupiter and Saturn rose together in opposition to the Sun. Pratt (1990) proposed the conjunction of Venus and Jupiter on 21 August 1 BC, because Venus was much brighter than Saturn. Martin (1998, p. 67-91) 
suggested the conjunction of Jupiter with the star Regulus on 14 September 3 BC. Sinnot (1968, p. 384-386) suggested the exceptional conjunction of Jupiter and Venus on 17 June 2 $\mathrm{BC}$, which were so near to appear as a single body, and so rare that can be seen (La Greca and De Caro 2020b) at most once in the whole life.

MV (2001a, p. 207-208), in her story of the Magi's journey, does mention a supernatural phenomenon, but she also writes that some astronomical calculations allowed the Magi to "decode" the meaning of real astronomical events. Therefore, astronomy is fundamental to understand the meaning of the Star of Bethlehem, as clarified in her writings (Valtorta 2001a; p. 211): «The oldest of the Magi...explains to Mary [Jesus' mother] that one night the previous December, they saw a new star of an unusual brightness appear in the sky. ... They had seen it and had striven to understand its meaning. They were happy to give up the little sleep they usually granted themselves and forgetting even their food, they devoted themselves entirely to studying the zodiac. And the conjunctions of the stars, the time, the season, the calculation of the hours passed and of the astronomical combinations had told them the name and the secret of the star. Its name: Messiah. Its secret: The Messiah had come to our world». In this citation there is a clear reference to conjunctions of astronomical bodies, calculations of the time elapsed between conjunctions and to their "decoding" directed to the birth of the Messiah. In synthesis, although the Star of Bethlehem supposedly did not coincide with a conjunction or with another astronomical event unknown to us - because the Star was supposedly supernatural -, the astronomical conjunctions accurately observed by the Magi, and suitably decoded, were the key to understand the "message" carried by this "star", i.e., the birth of the Messiah.

Notice that in the English translation, unfortunately, the curious expression of the original Italian text - set between quotation marks by MV - is lost. The writing style and use of Italian by MV are always excellent. She could write texts with many different registers, mathematically confirmed by the extension of her texts across the entire Italian literature (Matricciani et al 2018). Therefore, we must conclude that she wrote an unusual sentence on purpose, with the verb in the infinite form, not conjugated. In Italian (Valtorta 2001c) we read 
«Essere il Messia venuto al mondo», whose literal translation is: «To be the Messiah who came into the world». She seems reporting a literal translation of a sentence that conveys information only to readers who know how to decode it. The use of relationships between numbers and words - for either hiding information in texts or extracting meanings from numbers or interpreting dreams- was widespread in the Middle East, in the literature of magi (Derovan 2007) and, more generally, in the Greek-Roman world of 2000 years ago, as we will show in the next section.

\section{Astronomical events, Gematria, and chronology of Magi's journey to Palestine}

The correlation of numbers and words was a powerful and widespread coding/decoding technique in the Mediterranean Greek-Roman world, in the Middle East and in the Biblical culture (Derovan 2007) of 2000 years ago. In the following sub-sections, first we recall the Babylonian Normal Stars reference system used by ancient astronomers as coordinate system for studying the motion of planets. After, we show how the astronomical conjunctions of planets and stars were likely used for interpreting the Star of Bethlehem, associating words and sentences, through the Gematria (numerical values of words), to the time series of conjunctions of the years just before the beginning of Christian Era, and how the Magi could have applied them for planning their journey to Judea.

\subsection{The Babylonian Normal Stars reference system}

Venus, Jupiter, Mars, Mercury and Saturn, visible with naked eyes, during their apparent motion along the ecliptic, sometimes can be seen very near, an astronomical configuration called conjunction. Moreover, in their apparent motion they can appear to be in conjunction also with stars very near the ecliptic, where the apparent motion of planets occurs. In particular Regulus - the star alpha of the constellation of Lion, which etymologically means Little King - is very bright and very near the ecliptic and is the most important star of this constellation. In the Bible the Messiah is associated to the Lion of Judah (Apocalypse 5,5). To 
fully appreciate the importance of this star for ancient astronomers it is useful a brief insight about the Babylonian astronomy.

In Figure 2 we have drawn a circular plot showing the ecliptic longitude of the 32 Babylonian Normal Stars (Hunger et al 1988-1996) used as reference points for measuring the position of planets, as they were at the beginning of the Christian Era. Let us note that, due to the precession of equinoxes, since $600 \mathrm{BC}$ - when this reference system was already used (Hunger et al 1988-1996) - to the beginning of Christian Era, the reference pattern of these stars had rotated by about $\omega=8^{\circ}$, a value calculated with the proportion $\omega: 360^{\circ}=$ 600:25772, where 25772 years is the period of the precession motion (Hohenkerk et al 1992), as schematically shown in Figure 2.

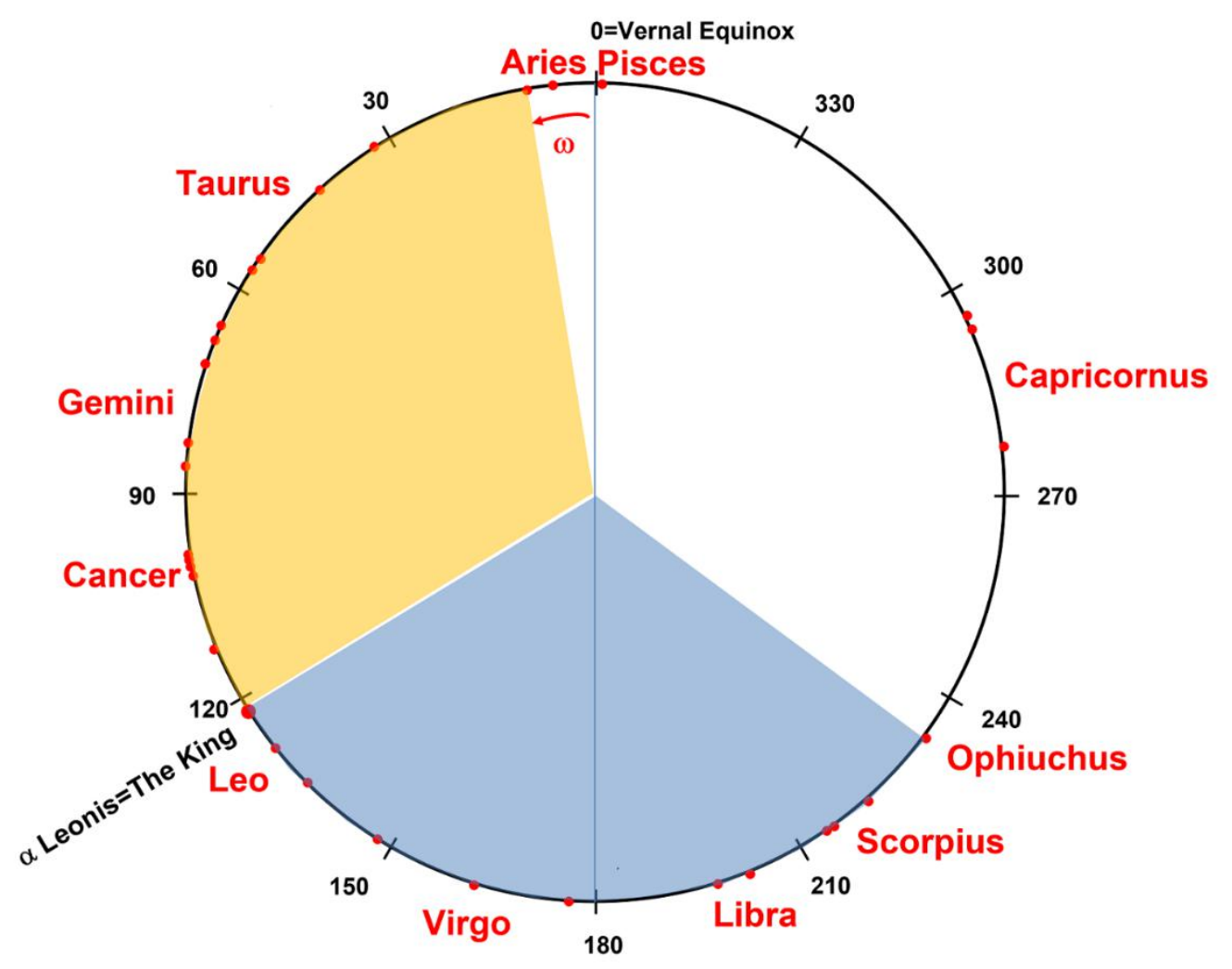

Figure 2. Circular plot showing the ecliptic longitude of the 32 Babylonian Normal Stars used as reference points to measure the position of planets, at the beginning of the Christian Era. The ecliptic latitude, at most few degrees in absolute value, is not shown. "The King" is the star also known as Regulus, named Lugal by Babylonians. 
The two-colored regions of Figure 2 evidence how important "The King" (Regulus) was in the reference system. In $600 \mathrm{BC}$ it was 112 degrees counterclockwise from the vernal equinox (yellow sector), and after exactly 112 degrees counterclockwise there was Ophiuchus, at the end of the blue sector. Beyond this ecliptic longitude the Normal Stars were rarer - only 3 out of 32, third (white) sector -, therefore, a region of the sky less important to ancient astronomers. The reason of the unevenly distribution of Normal Stars in ecliptic longitude is unknown (Hunger et al 1988-1996), although the graphic representation of Figure 2 seems to indicate it should be related to the importance of Regulus, named Lugal, i.e., "The King" by Eastern astronomers, in ancient Middle-East astronomy.

In conclusion, we can argue that Regulus should have played an important role in the reference system because it was very near the ecliptic, very bright and divided exactly in two halves the region of the sky with more Normal Stars, therefore, more frequently observed by ancient astronomers.

\subsection{The conjunctions of Jupiter, Venus and Regulus at the beginning of the Christian era}

Venus and Jupiter are two of the brightest planets in the sky. Their conjunction on 17 June 2 $\mathrm{BC}$ was particularly striking because the two planets seemed to be a single astronomical body - their angular distance was less than 1/60 of degree, therefore, below the resolution of naked-eye human vision (De Caro et al 2021b) -, a phenomenon extremely rare which occurs in a time scale of several centuries (Sinnot 1968; La Greca and De Caro 2020b). Therefore, this rare conjunction is useful for roughly setting the period of time, before the beginning of the Christian Era, in which search an astronomical conjunctions' series to be "decoded". Moreover, this rare conjunction occurred just after three consecutive conjunctions of Jupiter and Regulus, shown in Figure 3, in a very short interval, if compared with Jupiter's orbital period of about 12 years.

The loop of Jupiter positions shown in Figure 3, caused by its apparent retrograde motion, is called opposition or retrograde loop. In fact, planets appear to switch direction periodically in 
the sky and generally they drift slowly eastward relative to the stars. Since the Earth completes its orbit in a shorter period than the planets outside its orbit (III Kepler's Law), it periodically overtakes them. When this occurs, the planet being passed first appears to stop its eastward drift, and then to drift back westward. Then, as the Earth swings past the planet, the planet appears to resume its normal motion West to East (Carrol et al 2007). What is schematically shown in Figure 3 is an astronomical configuration not frequently seen in the sky: an event the Magi could have seen only once in their all life. Indeed, because the orbital period of Jupiter is 11.86 years, finding Jupiter's retrograde motion occurring just near Regulus and, at the same, also finding near Regulus also Venus, we need to find an integer number of years which, divided by the orbital periods of Venus and Jupiter, gives an integer number.

The orbital period of Venus is 0.615198 years and 135 orbital revolutions of Venus give $135 \times 0.615198=83.053$ years, i.e., almost the same value obtained after 7 orbital revolutions of Jupiter $(7 \times 11.86=83.02)$. Therefore, about after 83 years, we would observe three consecutive Jupiter-Regulus conjunctions, and the presence of Venus near Regulus, as it occurred at the beginning of the Christian era. To be more precise, in 510 years there are 43.002 orbital revolutions of Jupiter and 829.001 orbital revolutions of Venus; thus, only after 510 years - the approximation is on the third decimal digit - there is a series of conjunctions very similar to the one seen in the years just before the beginning of the Christian Era. Therefore, the Magi could have seen the series of conjunctions here described only once in their life, and its peculiarities could have attracted their attention. 


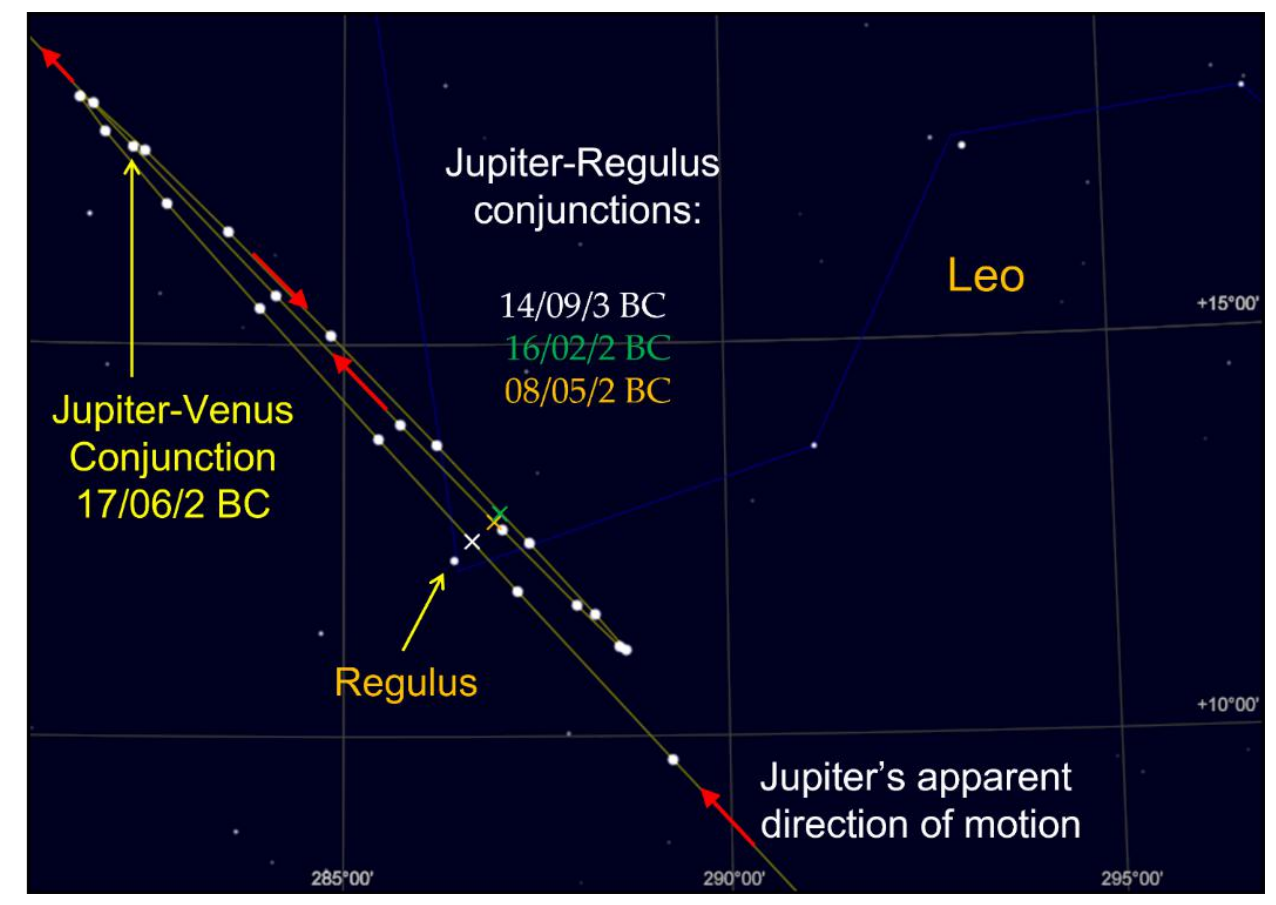

Figure 3. Three consecutive conjunctions of Jupiter and Regulus, and the following conjunction of Jupiter and Venus, each other so near to appear a single astronomical body. The change of direction of the red arrows indicates the change of apparent motion's direction of Jupiter: first, from direct to retrograde motion; then, from retrograde to direct motion. When this occurs near a fixed star, Regulus in the figure, it is possible to observe three consecutive conjunctions of the planet with this star, in a short interval. Points in the figure indicate Jupiter's position every two weeks. Crosses indicate Jupiter's positions during the three consecutive conjunctions with Regulus.

Given the above premises, we focus our research mainly on the astronomical conjunctions of Jupiter, Venus and Regulus. It is not casual that several scholars (Sinnot 1968; Pratt 1990; Martin 1998) have often associated them to the Star of Bethlehem.

\subsection{Decoding times series of conjunctions for interpreting the Star of Bethlehem}

To assign a meaning to integer numbers expressing the time elapsed between conjunctions, we must share the culture of that time, when a numerical and verbal meaning was assigned to each letter of the Hebrew alphabet, to words and sentences. We recall, for example, the well-known association of the integer 666 to the Beast of Apocalypse $(13,18)$. In support of our working hypothesis, we recall that in the Hellenistic literature of magi, oriental experts in interpreting dreams and future events, the use of Gematria (Derovan 2007) was widespread. Gematria was also employed by some Church Fathers (Méhat 1966; Farrar 1961; Lieberman 
1987). The first use of Gematria is found in an inscription (Derovan 2007) by Sargon II (727$707 \mathrm{BC})$, therefore this coding/decoding technique was diffused in the region where the Magi, the Wise Men of Matthew 2, are supposed to come from and, consequently, we can assume that they used this technique for interpreting the meaning of the Star of Bethlehem.

We suppose that the astronomers of 2000 years ago interpreted the intervals between astronomical conjunctions as prediction of important events - such as the birth of a king - by using the alphanumeric code of the Hebrew Gematria. This coding technique was widespread in the Roman Empire. For example, in Pompeii on a graffiti it is written (Ian 2018): «I love her whose number is 545»: a coded love's secret. In Matthew, Jesus' genealogy (Mt, 1) has been investigated (Bryan 2020) according to a simple form of this coding. Moreover, also the observation of the night sky for searching signs of particular meaning, such as God's benevolence, was common, as in the victory of Emperor Constantine over Maxentius when, perhaps, the Christian symbol Chi-Ro was seen (Di Maio et al 1988) in the sky the night before the decisive battle of the Milvian Bridge in 312 AD.

Therefore, we have assumed the Magi used Hebrew to decode the astronomical conjunction's series, a language very diffuse in the region of Chaldean astronomers, since they surely know that only the Jews were waiting for their king, the Messiah. Moreover, we have assumed the alphanumeric code defined "absolute value", in Hebrew Mispar Hechrachi, because this is the standard method of Gematria (Michalski 2021; Davis 1968). It divides the alphabet's 22 letters into 3 sections: the first 9 letters range from 1 - aleph [x] to 9 - tet [ט]. The next 9 letters range from 10 - yod [י] to 90 - tsade [ $३$ ]. The other 4 letters are expressed in hundreds. It means that the letter qof [ק] has value 100, and the last letter of the alphabet tav [ת] is 400 . Vowels have no value in this coding.

To determine an interval suitable for searching series of conjunctions to decode according to Gematria, we suppose the Magi considered some conjunctions Jupiter-Venus and Venus-Regulus occurred just before the rare conjunction on 17 June 2 BC (blue in Table 2) and the three consecutive conjunctions of Jupiter with Regulus (green in Table 2). Then, according to our hypothesis, going back with respect to 17 June $2 \mathrm{BC}$, they chose one of these 
conjunctions as starting point for counting the time elapsed, in days, from other conjunctions. To these intervals they assigned a meaning through Gematria. Very likely they set the first conjunction/starting point for the counting by trial and error, until a full-meaning sentence or series of words making a meaningful sentence was obtained.

To verify the above conjecture, derived from the mystical writings of MV, we have applied the Gematria coding/decoding scheme, to associate to the number of days elapsed between conjunctions a possible messianic meaning, reported in Table 2, according to the following steps: start with the number in column 3 (the time elapsed between conjunctions), then decode this number according to the Hebrew Gematria, therefore obtaining the Hebrew word reported in column 4. The word, translated in Italian (or in English) reveals unexpected coincidence of meaning with the sentences written by MV.

We note that all the conjunctions, to which it is possible to associate a meaning, according to MV's writings, involve Regulus. This unexpected finding should be related to the importance of this star between the 32 reference Normal Stars (see Figure 2), justifying why the Magi would pay their attention just to these particular conjunctions. All the conjunctions with associated a messianic meaning fall in a short period of only 10 months before the striking Venus-Jupiter conjunction on 17 June 2 BC.

By using Gematria, we note the strong correlations with MV's original sentences. In English, we find:

1) «To be [...] who came into the world» should be compared with MV's sentence «To be the Messiah who came into the world»;

2) «His name is Messiah» should be compared with the MV's sentence «His name: Messiah».

Table 2. Astronomical conjunctions, time elapsed between them and its decoding according to Gematria, with possible meaning coinciding with $\mathrm{MV}^{\prime}$ s original sentences «essere il Messia venuto al mondo» and «il suo nome: Messia». Column 1 lists the conjunctions; column 2 gives the date of the conjunction. By associating numbers to letters of the Hebrew 
alphabet, according to Gematria, we have verified that the Magi could have obtained some words and sentences, which unexpectedly coincide with those written (in italics) by MV, associable to the birth of the King of the Jews, the Messiah (Mt 2). Green highlights the triple Jupiter-Regulus conjunction. Blue highlights the rare Venus-Jupiter conjunction when the two planets were indistinguishable with naked eyes.

\begin{tabular}{|c|c|c|c|}
\hline Conjunction & $\begin{array}{c}\text { Date } \\
\text { (Chevalley 2006) }\end{array}$ & Interval (Days) & $\begin{array}{l}\text { Possible meaning associated to the } \\
\text { Messiah }\end{array}$ \\
\hline Jupiter, Venus & $23 / 05 / 4 \mathrm{BC}$ & 0 & Start counting \\
\hline Venus, Regulus & 02/07/4 BC & 40 & \\
\hline Jupiter, Venus & $12 / 08 / 3 \mathrm{BC}$ & 446 & \\
\hline Venus, Regulus & $17 / 08 / 3 \mathrm{BC}$ & 451 & To be (להיות) \\
\hline $\begin{array}{l}\text { Jupiter, Regulus } \\
\text { (Martin 1998) }\end{array}$ & $14 / 09 / 3 \mathrm{BC}$ & 479 & ...who came into the world (שבא לעולם...) \\
\hline Jupiter, Regulus & $16 / 02 / 2 \mathrm{BC}$ & 634 & \\
\hline \multirow{2}{*}{ Jupiter, Regulus } & 08/05/2 BC & 715 & \\
\hline & 09/05/2 BC & $716\left(^{*}\right)$ & His name is Messiah (שמו הוא משיח) \\
\hline Venus, Regulus & $11 / 06 / 2 \mathrm{BC}$ & 749 & \\
\hline $\begin{array}{l}\text { Jupiter, Venus } \\
\text { (Sinnot 1968) }\end{array}$ & $17 / 06 / 2 \mathrm{BC}$ & 755 & \\
\hline
\end{tabular}

$\left.{ }^{*}\right)$ The angular distance between Jupiter and Regulus has changed from 8 to 9 May 2 BC of only about 7 $\operatorname{arcsecs}(1 / 3600$ of degree), well below the angular resolution of human vision with naked eyes (De Caro et al 2021b), close to 1 arcmin (1/60 of degree). Therefore, in our analysis we have considered both dates.

These unexpected correlations require a more accurate analysis, done in the following sub-sections, starting from checking chronological coherence of Magi's story and their journey to Judea, by using some data reported by Josephus (Leeming et al 2003), which integrate Matthew's narration (Mt 2), and the historical constraints on Herod's death (La Greca and De Caro 2019; De Caro et al 2021b). 


\subsection{Chronology of Magi's journey to Judea according to MV's mistycal writings}

Let us note that, according to the MV's writings (2001a, p. 213), the Magi arrived in Judea when Jesus was already able to walk, although held up by Mary's and one of the Magi hands. More precisely, MV indicates Jesus' age between 9 and 12 months (Valtorta 2001a, p. 210). Table 3 reports a possible chronological reconstruction of the Magi's journey to Judea, according to these chronological indications. If Jesus was about 1 year old, then the sentence «one night the previous December», referring to the time when the Magi saw the star, might refer to December $1 \mathrm{BC}$.

The Magi are mentioned not only in Matthew but also in a version of The Jewish war, by Josephus, written in ancient Russian (Leeming et al 2003, p. 179-181), discovered in 1866, supposedly a translation of an original version written in Hebrew. This version narrates facts not reported in the Greek version, even if it is about 15\% shorter. Recent studies (Nodet 2011) consider it authentic, not interpolated by Christian writers. In this version it is explicitly said that the Star of Bethlehem is neither a planet nor a comet or any other known astronomical body.

According also to this version, the Magi did not arrive at Bethlehem just after they saw the Star - they supposedly studied the sky for about 1.5 years before reaching Bethlehem (Leeming et al 2003; p. 179-181) -, and the massacre of all boys, ordered by Herod The Great, would have occurred 1 year after their arrival. Herod may have interpreted the eclipse of November 2 AD - recently associated with his death (La Greca and De Caro 2019; De Caro et al 2021b) - as a deadly sign for his continuously worsening health and pushed him to kill his son (Josephus, $J W$ I.665) and the boys under age 2. The time correlation of the eclipse and the massacre of the boys could be an indirect confirmation that this is the eclipse associated by Josephus in Jewish Antiquities with Herod's death.

Table 3. Chronological reconstruction of the Magi's journey to Judea.

\begin{tabular}{c|l|l}
\hline $\begin{array}{c}\text { Star of Bethlehem, } \\
\text { seen by the Magi }\end{array}$ & December 1 BC & $\begin{array}{l}\text { The Magi (Valtorta 2001a, p. 211) saw the Star. It is } \\
\text { a supernatural phenomenon. No known astronomical } \\
\text { events can be associated to it. }\end{array}$ \\
\hline
\end{tabular}




\begin{tabular}{c|c|l}
\hline $\begin{array}{c}\text { The Magi arrived at } \\
\text { Bethlehem }\end{array}$ & End of Autumn 1 AD & $\begin{array}{l}\text { The Magi studied the astronomical conjunctions, } \\
\text { observed before December 1 BC, for understanding } \\
\text { the meaning of the Star (see Table 2). Only after this } \\
\text { long analysis (Valtorta 2021a, p. 211) they decided } \\
\text { to leave for Judea. }\end{array}$ \\
\hline $\begin{array}{c}\text { Moon Eclipse before } \\
\text { Herod's Death }\end{array}$ & $\begin{array}{c}\text { 8-9 November 2 AD (La } \\
\text { Greca and De Caro 2019; } \\
\text { De Caro et al 2021b) }\end{array}$ & Autumn 2 AD \\
$\begin{array}{c}\text { Massacre of all boys } \\
\text { under age 2 }\end{array}$ & $\begin{array}{l}\text { Bethlehem and its vicinity two years old and under, } \\
\text { in accordance with the time he had ascertained from } \\
\text { the Magi» (Mt 2,16) }\end{array}$ \\
\hline Herod's Death & $\begin{array}{c}\text { 24/01/3 AD (La Greca } \\
\text { and De Caro 2019; De } \\
\text { Caro et al 2021b) }\end{array}$ & \\
\hline
\end{tabular}

In conclusion, the findings reported in Table 2 reveal a coherent chronological framework, compatible with known historically constraints and ancient literary sources.

Is it all just a case? Our further analysis, in the next Section, of all conjunctions between Venus, Jupiter and Regulus, studied and interpreted as the Magi would have likely done, aims at finding an answer to this question.

\section{A messianic sentence derived from astronomical conjunctions' series}

Let us examine all conjunctions occurred in the years $4 \mathrm{BC}$ to $2 \mathrm{BC}$, before the Venus-Jupiter conjunction of 17 June $2 \mathrm{BC}$, and "decode" them according to Gematria, as the Magi could have done. Table 4 reports the conjunctions and their decoding with reference to the coming of the Messiah, as done in Table 2.

It is really unexpected that it is possible to extract a meaningful sentence correlated with the coming of the Messiah, according to New Testament narration and to the chronological reconstruction of the Nativity previously proposed.

The sentence is the following:

A good Father and loving, My God has come, to be ... who came into the world on year's eve. 
At the mouth of the cave / His name is Messiah to be light at Hanukkah.

God chose him to be the redemption of the Messiah, son of David.

We note the following amazing coincidences with what we are discussing about Jesus' Nativity:

1) The "codified message" can be considered as constituted by two parts with different chronological information: the first concerns the conception, the second the birth.

2) In the Hebrew Calendar, the year's eve, i.e., the end of the last month of the year, is the end of Adar/Adar II. We have already discussed in Section 3 as the chronological information contained in the Gospels, in synergy with Jewish pilgrimages' traditions and Nativity Day set on 25 Kislev, leads to set Jesus' conception, nine months before, at the end of the month of Adar II, i.e., just on year's eve. From the end of Adar II to Kislev 25 there are 9 full lunar months, therefore $9 \times 29.53=266$ days, exactly 38 weeks. Now, counting weeks from conception, 38 weeks is just the duration of pregnancy at birth (Chow et al 2009). As 40 weeks elapse from the last menstruation, the Annunciation and Conception occurred in Mary's fertile days.

3) The exact place of birth is not revealed, although it refers to a cave (Mt, 2); its exact localization is preserved, in agreement with the narration of the Magi $(\mathrm{Mt}, 2)$, who do not know where the king was born. However, there is an explicit reference to David, the first king of the Hebrews, thus indicating the reign of Judah.

4) Note the last amazing coincidence: Kislev 25 is the beginning of Hanukkah, fully correlated with the conception on year's eve of the Hebrew Calendar (end of Adar II).

Therefore, if we were ancient Christian astronomers studying the motion of astronomical bodies for obtaining information regarding important historical/religious events, we would have felt satisfied and stopped the research. The chronological information about the year's eve, related either to the beginning of winter - if referred to the Julian Calendar -, or to the end of the winter - if referred to the Hebrew calendar -, would have prompted us to stop. Reasonably, experts as the Magi could have considered the chronological findings decisive 
for planning their journey, but only after fully decoding the "divine message" by means of the complex astronomical and linguistic analysis summarized in Table 4.

All the above findings, of course, could be due to case. To get rid of causality, let us roughly estimate the (maximum) probability $p_{k}$ of obtaining the meaningful sentence (red text in Table 5) about the Messiah, by considering all possible sentences, either meaningful or not. We have searched more meanings obtainable from the number of days elapsed between conjunctions, by searching in a database (Heidrick 2021) dedicated to Gematria, whose results are listed in Table 5.

Table 4. Astronomical conjunctions between Venus, Jupiter and Regulus, occurred in the years 4 BC to 2 $\mathrm{BC}$, and possible association of words and sentences to the coming of the Messiah, decoded according to Gematria, as done in Table 2.

\begin{tabular}{|c|c|c|c|}
\hline Conjunction & $\begin{array}{c}\text { Date (BC) } \\
\text { (Chevalley 2006) }\end{array}$ & $\begin{array}{l}\text { Interval } \\
\text { (Days) }\end{array}$ & Possible meaning associated to the Messiah \\
\hline Jupiter, Venus & $23 / 05 / 4$ & 0 & Start counting \\
\hline Venus, Regulus & $02 / 07 / 4$ & 40 & A good Father and loving (אב טוב ואוהב) \\
\hline Jupiter, Venus & $12 / 08 / 3$ & 446 & My God has come (אליתה) \\
\hline Venus, Regulus & $17 / 08 / 3$ & 451 & To be (להיות) \\
\hline Jupiter, Regulus & $14 / 09 / 3$ & 479 & ...who came into the world (שבא לעולם...) \\
\hline Jupiter, Regulus & $16 / 02 / 2$ & 634 & On year's eve (בערב השנה) \\
\hline \multirow{2}{*}{ Jupiter, Regulus } & $08 / 05 / 2$ & 715 & At the mouth of the cave (מערתה) \\
\hline & $09 / 05 / 2$ & 716 & His name is Messiah (שמו הוא משיח) \\
\hline Venus, Regulus & $11 / 06 / 2$ & 749 & To be light at Hanukkah (להיות אור בחנוכה) \\
\hline Jupiter, Venus & $17 / 06 / 2$ & 755 & God chose him to be (אלהים בחר בו להיות) \\
\hline Jupiter, Venus & $14 / 10 / 2$ & 874 & $\begin{array}{l}\text { The redemption of the Messiah, son of David } \\
\text { (גאולת משיח בן דויד) }\end{array}$ \\
\hline
\end{tabular}

The value of the probability (see Appendix A) is extremely low. In Table 5 there are $N_{k}=$ 2558 possible random connections, therefore, $p_{k}=1 / 2558 \cong 0.04 \%$. In other words, very 
likely only 1 out of 2558 possible series of words is meaningful and refers to the Messiah. Obviously, Table 5 could be filled by many other entries, searching in Hebrew many more combinations corresponding to the same integer, therefore, $0.04 \%$ could be also overly pessimistic. In fact, widening the search on a larger set of words, very likely would produce further sentences with messianic meaning, but also many more words with no such a meaning, therefore the order of magnitude of the probability estimated should not change.

Table 5. Astronomical conjunctions (column 1) occurred in the years $4 \mathrm{BC}$ to $2 \mathrm{BC}$ (column 2), time (interval) elapsed between them (column 3) and all possible words and meanings (column 4, given by the number $n_{i}$ ) associated by Gematria. The words in red bold form the meaningful sentence on the Messiah.

\begin{tabular}{|c|c|c|c|}
\hline Conjunction & $\begin{array}{l}\text { Date } \\
\text { (BC) }\end{array}$ & \begin{tabular}{|c} 
Interval \\
(Days) \\
(Chevalley \\
2006)
\end{tabular} & $\begin{array}{l}\text { Possible meanings associable to the integer expressing the time } \\
\text { elapsed }\end{array}$ \\
\hline Start counting & $23 / 05 / 4$ & 0 & \\
\hline $\begin{array}{l}\text { Venus, } \\
\text { Regulus }\end{array}$ & $03 / 07 / 4$ & 40 & $\begin{array}{l}\text { A good Father and loving, "Deceptive", loathing; to loath, to abhor, } \\
\text { "Brightness", "Son of Strife", to cut, strip off, flay; to tear, snatch away, } \\
\text { seize; to rob, steal, plunder; evaporate water; peep, twitter, to bear, bring } \\
\text { forth; child, off-spring, to draw, lift out, a Jewess, to wrap together, } \\
\text { twist, bind; to bind, pledge; act torturously; to wound, to hurt, to destroy; } \\
\text { to overthrow; writhing (labor pains); pangs; cord, rope, measuring line; a } \\
\text { portion, an estate; a district, region; a snare, a toil; a band, a troop; } \\
\text { destruction, desolation; hurt, harm; pledge; perverseness; a rope-man, } \\
\text { shipman, sailor; a cable, ship's cable; a mast, helm, to stick on, smear } \\
\text { over; to be sticky, greasy, fat; to be white; milk, fresh milk; fatness; the } \\
\text { best part, to hang about, to be torn; to be mended in pieces or patches, } \\
\text { "Yah Sees", in secret, stealthily; to conceal or hide; to utter privily or } \\
\text { softly; gentleness; gently, to languish or faint; to wander or err, to act or } \\
\text { speak rashly or foolishly, to be burnt, swarthy, to hide, if not; whether } \\
\text { not; perhaps; unless. } n_{1}=101 \text {. }\end{array}$ \\
\hline Jupiter, Venus & $12 / 08 / 3$ & 446 & $\begin{array}{l}\text { My God has come, My God comes, an unclean bird, twilight or evening } \\
\text { bird, owl or a bittern or heron, a noose or snare, a ring, a plot, stratagem, } \\
\text { a plotter, to die, to wither up, to lie waste, to faint, to perish, death, place } \\
\text { of the dead, destruction or ruin, a hollow way or narrow pass. } n_{2}=25 \text {. }\end{array}$ \\
\hline $\begin{array}{l}\text { Venus, } \\
\text { Regulus }\end{array}$ & $17 / 08 / 3$ & 451 & $\begin{array}{l}\text { To be, to become, to exist, to happen, complete, "God Hears", } \\
\text { "Truthful", to incline to, to meet, to take short steps, persistent, ye, to } \\
\text { mock or deride, Ishmael, loops, snare, plot, "Shinanim". } n_{3}=19\end{array}$ \\
\hline Jupiter, & $14 / 09 / 3$ & 479 & Who came into the world. $n_{4}=1$. \\
\hline
\end{tabular}




\begin{tabular}{c|c|c|l}
\hline Regulus & & & \\
\hline $\begin{array}{c}\text { Jupiter, } \\
\text { Regulus }\end{array}$ & $16 / 02 / 2$ & 634 & On the year's eve, avenging of blood. $n_{5}=2$ \\
\hline $\begin{array}{c}\text { Jupiter, } \\
\text { Regulus }\end{array}$ & $08 / 05 / 2$ & 715 & At the mouth of the cave, a foreign land, a people deep of lip. $n_{6}=3$. \\
\hline $\begin{array}{c}\text { Venus, } \\
\text { Regulus }\end{array}$ & $11 / 06 / 2$ & 749 & To be light at Hanukkah, a censer. $n_{7}=2$. \\
\hline $\begin{array}{c}\text { Venus, Jupiter } \\
\text { Venus, Jupiter }\end{array}$ & $17 / 06 / 2$ & 755 & God chose him to be, hard of neck, stubborn. $n_{8}=3$ \\
\hline
\end{tabular}

In the next Section we will examine the astronomical dating of the crucifixion, which can be closely related to the Nativity Day just discussed, through Jesus' age of 1737 weeks, as stated by MV (1993).

\section{Jesus' death: the more probable dates of crucifixion}

Pontius Pilate ruled Judea from 26 to 36 AD, dates (Tacitus, Ann. XV. 44; Josephus, AJ XVIII. 35; 55-64; 85-89; 177) shared my most scholars (Wright et al 2002). The four canonical gospels agree in reporting that Jesus died in the afternoon of a Friday. For Matthew, Mark and Luke (synoptic gospels) that Friday was 15 Nisan, the day of Passover. For John, that Friday was not Passover, because there are elements referring to 14 Nisan (John, 18,28; 19,31). Passover lambs were immolated from 15 to 17 PM of 14 Nisan (Josephus, BJ VI. 423), and only just after the sunset, in the new day, the Passover supper started.

In Table 6 we have listed the possible dates of Jesus' death, according to astronomical calculations, most of which already proposed in previous studies (La Greca and De Caro 2017; Finegan 1998; Fotheringham 1934; Nothaf 2012b; Strobel 1977; Schaefer 1990; Bond 2013; Humphreys et al 1983; Humphreys et al 1992; Ruggles 1990). 
Table 6. Julian dates of 14 Nisan astronomically calculated in the years 26 to 36 AD. When 14 or 15 Nisan fall on Friday, the Julian date is highlighted in bold. In red the only two consecutive Passovers fell on Saturday, as described by MV in her Jesus' life (Matricciani and De Caro 2017).

\begin{tabular}{|c|c|c|c|}
\hline Year & $\begin{array}{l}\text { Beginning of crescent Moon } \\
\text { (Fraction illuminated, \%) }\end{array}$ & 14 Nisan & 15 Nisan \\
\hline 26 & 7 April (3.4) & Sunday, 21 April & Monday, 22 April \\
\hline \multirow[t]{2}{*}{27} & $27 \operatorname{March}(1.1)$ & Thursday, 10 April & Friday, 11 April \\
\hline & $28 \operatorname{March}(4.7)$ & Friday, 11 April & Saturday, 12 April \\
\hline 28 & $16 \operatorname{March}(2.8)$ & Tuesday, 30 March & Wednesday, 31 March \\
\hline \multirow[t]{2}{*}{$28 \mathrm{E}$} & 14 April (1.3) & Wednesday, 28 April & Thursday, 29 April \\
\hline & 15 April (4.9) & Thursday, 29 April & Friday, 30 April \\
\hline 29 & 4 April (3.5) & Monday, 18 April & Tuesday, 19 April \\
\hline 30 & $24 \operatorname{March}(3.4)$ & Friday, 7 April & Saturday, 8 April \\
\hline 31 & $13 \operatorname{March}(3.3)$ & Tuesday, 27 March & Wednesday, 28 March \\
\hline \multirow[t]{2}{*}{$31 \mathrm{E}$} & 11 April (1.4) & Wednesday, 25 April & Thursday, 26 April \\
\hline & 12 April (4.6) & Thursday, 26 April & Friday, 27 April \\
\hline 32 & $31 \operatorname{March}(4.1)$ & Monday, 14 April & Tuesday, 15 April \\
\hline 33 & $20 \operatorname{March}(2.4)$ & Friday, 3 April & Saturday, 4 April \\
\hline \multirow[t]{2}{*}{$33 \mathrm{E}$} & 18 April (1.2) & Saturday, 2 May & Sunday, 3 May \\
\hline & 19 April (5.0) & Sunday, 3 May & Monday, 4 May \\
\hline 34 & $10 \operatorname{March}(3.6)$ & Wednesday, 24 March & Thursday, 25 March \\
\hline $34 \mathrm{E}$ & 8 April (2.3) & Thursday, 22 April & Friday, 23 April \\
\hline
\end{tabular}




\begin{tabular}{c|c|c|c}
\hline & $\begin{array}{c}\text { 9 April (with a delay of 1 day: } \\
\text { see main text) }\end{array}$ & Friday, 23 April & Saturday, 24 April \\
\hline 35 & $29 \operatorname{March}(3.4)$ & Tuesday, 12 April & Wednesday, 13 April \\
\hline 36 & 17 March (1.3) & Saturday, 31 March & Sunday, 1 April \\
\hline $36 \mathrm{E}$ & 18 March (4.5) & Sunday, 1 April & Monday, 2 April \\
\hline
\end{tabular}

The years indicated in column 1 are calculated according to the Christian Era (AD), established by Dionysius Exiguus, recently re-examined and confirmed (La Greca and De Caro 2019, De Caro et al 2021b). The days indicated refer to the Julian calendar, with the convention that the day starts at the sixth hour of 14 Nisan and ends at the sixth hour of 15 Nisan. "E" stands for embolismic year (of 13 months).

Column 2 lists the day of first visibility of the crescent moon (with indicated the fraction of moon's surface illuminated), calculated with Skychart (Chevalley 2006). The first day of Nisan starts at the sunset of the Julian day and ends at the sunset of next day. There are also some variants occurring when the moon was not visible - either for a low percentage of surface illuminated or for bad weather - therefore, delaying by 1 day the beginning of the next month. However, we have considered explicitly this hypothesis only when 14 or 15 Nisan falls on Friday, and when the fraction of moon's surface illuminated is $2.5 \%$ maximum, because for larger values the month just finished would have already been of 30 days (see Section 2).

In favorable meteorological conditions, the beginning of the month of Nisan could have been anticipated by 1 day, but we have assumed that this occurred only when the fraction of moon's surface illuminated was at least $1 \%$. Column 3 lists the date corresponding to 14 Nisan, day of crucifixion according to the Synoptics.

The dates when 14 Nisan was Friday (according to John) or 15 Nisan (according to the Synoptics) are in bold. Notice that the delay of 1 month in the beginning of the following year 
could make the Passover fall at the beginning of May. This situation was possible in the Babylonian calendar (Parker et al 1956) and was explicitly considered (Finegan 1998, p. 365) also in the dates of crucifixion of the year 33, reported in Table 6. In summary, by assuming the chronology of John, we get the following Julian dates for Friday, day of crucifixion:

a) 11 April 27. This date assumes a delay of 1 day in the beginning of Nisan. The delay is plausible because the moon's surface illuminated was only $1.1 \%$, hardly visible on 27 March, first day of the new moon. Very likely, the month of Nisan started on 28 March. This dating is hardly reconcilable with the fifteenth year of reign of the Emperor Tiberius, beginning of John the Baptist's ministry and Jesus' public life, according to Luke (La Greca and De Caro 2017)

b) 7 April 30. It is the most probable date since the end of the nineteenth century, because it correlates well both with the patristic tradition on the age of Jesus at his death - about 33 years -, and with the date of Herod's death set in 4 BC (Finegan 1998, p. 367).

c) 3 April 33. Before the studies of the end of XIX and beginning XX centuries, this date was considered the most probable for the crucifixion (Nothaf 2012b, p. 273-274), but always assuming Herod died in 4 BC (Bond 2013; Finegan 1998, p. 291-301). It was re-proposed in the 1980's (Humphreys et al 1983; Humphreys et al 1992) because of the occurrence of an eclipse of moon on the day of crucifixion, correlated, by the authors, with Peter's speech on the day of Pentecost (Acts 2,20, Joel 3, 4). Other authors (Schaefer 1990; Ruggles 1990), however, doubt the eclipse was visible from Jerusalem.

d) 23 April 34. It is a possible date if (La Greca and De Caro 2017): (a) an embolismic year is assumed - because in March, as evidenced in Table 6, Passover would have fallen almost in coincidence with the day of the equinox (only 2 days later) - and (b) if a delay of 1 day is introduced in Nisan because of a possible insufficient visibility of the crescent moon the first day due to adverse meteorological conditions.

In principle, according to the Synoptics, the day of crucifixion was 15 not 14 Nisan. In this case Friday 15 Nisan could correspond to 11 April 27, 30 April 28, 27 April 31 or 23 April 34. 
This last date, therefore, without supposing any delay in the beginning of the lunar month, would have been Friday 15 Nisan, according to the Synoptics. It is interesting to notice the year 34 is the only one that is always a possible year of crucifixion, whichever is the chronology considered. The other years, in fact, depend on the chronology assumed, Synoptics' or John's.

Now, also 25 March 34 could have been 15 Nisan, but it was Thursday not Friday (Nothaf 2012b). Therefore, within an error of only 1 day of the week, 25 March 34 is the day nearest to the ancient tradition of crucifixion. It is therefore possible to suppose that one of the early Christian chronographs - such as Ippolito, Section 3 - calculated this date with an error of 1 day, correlating conception and death at the same day: March 25.

We have already noted that for John the Last Supper was not during Passover, but it was an evening supper begun just after the sunset of 13 Nisan, that is, at the beginning of Nisan 14 . Therefore, it seems that the Gospels, on one of the most important and central moments in Jesus' life, disagree. However, the disagreement may be only apparent (Strack et al 1924; Lichtenstein 1913).

Strack and Billerbeck (Strack et al 1924), in fact, hypothesized that in some years the Pharisees and Sadducees could calculate the beginning of the month of Nisan with 1-day difference. The cause would be related to Leviticus 23,10-11: «... you shall bring a sheaf of the first fruits of your harvest to the priest, who shall wave the sheaf before the Lord that it may be acceptable for you. On the day after the Sabbath the priest shall do this. " The rite was to be done on Nisan 16 and, at the same time, it had to fall on the day after the Sabbath, because shaking the sheaves of the first fruits required a considerable effort and, therefore, physical work that was forbidden on Sabbath.

If, however, Nisan 15 fell on a Friday, then Nisan 16 would have coincided with a Saturday and the rite of offering the sheaves - that began the calculation of the seven weeks establishing the set Pentecost -, could not take place, according to the prescription of Leviticus, which expressly required «the day after the Sabbath». This would be the case in the 
year of Jesus' crucifixion. The priests of the Temple followed this Levitical prescription carefully, therefore, when Nisan 15 coincided with a Friday, they delayed the beginning of the month of Nisan by 1 day. On the contrary, the Pharisees, and a part of the people less linked to the Sadducees, calculated the beginning of Nisan according to the actual new moon. Therefore, if Nisan 15 fell on a Friday, they did not delay Passover by 1 day, because they had no servile work to do related to the offering of sheaves in the Temple the following day. Therefore, in the year when Jesus was crucified, the Pharisees and a part of the people would have celebrated Passover on Friday. On the contrary, Sadducees, priests, their families, servants, and guards of the Temple, in other words, all those who directly or indirectly depended on the ritual activities of the Temple, would have delayed Passover to the next day, the Sabbath. In conclusion, the Synoptics would have descripted the Pharisees' and common people's Passover, John would have descripted the Priests' and Sadducees' one.

Although this explanation is plausible, it has not gained much consensus among scholars, despite being well motivated by the scriptural reference to Leviticus. The reason is the obvious fact that not every year Nisan 15 falls on a Friday. We have already mentioned that this certainly occurred in four years: 11 April 27; 30 April 28; 27 April 31; 23 April 34.

Strack's and Billerbeck's hypothesis, indeed, cannot be applied to the years 30 and 33, considered by most scholars a possible date of the crucifixion. In fact, both in 30 and in 33, Friday coincides with Nisan 14, not with 15, therefore with the eve not with Passover. Consequently, in both years Nisan 16 should have been the day after Saturday (see Table 6). The prescription on the day of the offering of sheaves, therefore, would have been already satisfied, without delaying the beginning of Nisan. For this reason, the years 30 and 33 are compatible only with John's chronology.

To fully reconcile the Synoptics with John it suffices to consider a year when the full moon and Passover fell on Friday, not on Saturday. The year 34 satisfies both conditions hypothesized by Strack and Billerbeck: on Thursday evening - 22 April 34 - Jesus would have celebrated Passover with his disciples (Last Supper), because 15 days since a new moon 
had just elapsed, after sunset. The priests, however, for the reasons explained above, were forced to delay Passover by 1 day.

Friday 11 April 27 or Friday 30 April 28 - other possible days coinciding with 15 Nisan- are too early to be reconcilable with the chronological constraint of being in the fifteenth year of Emperor Tiberius $(\mathrm{Lk}, 3)$.

Friday 27 April 31, which may have been Nisan 15 in the case of an embolismic year, must also be excluded because, as shown in Table 6, on 12 April 31, i.e. the beginning of Nisan, a substantial fraction $4.6 \%$, of the lunar disk was already visible at sunset, because 53 hours had passed from the new moon (i.e., conjunction with the sun) occurred at about 13:30 on April 10. For this reason, several scholars (Finegan 1998, p. 363) anticipate the beginning of Nisan of the year 31 by 1 day, therefore forcing 15 Nisan on Thursday 26 April. Therefore, the eve of Passover was not a Friday.

For 23 April 34 the astronomical analysis shows that the situation is completely different. To make Nisan 15 a Friday would require that the beginning of Nisan occurred about 30 hours after the new moon, that is 1 day earlier than in the year 31, which makes Nisan 15 to be a Friday for the year 34 but not for 31 .

\section{Jesus' conception and death dating according to MV's writings}

MV never indicates the year of Crucifixion. In her writings there are many narrative elements that convey chronological information like days of worship rest, references to major Jewish holy days, market days, seasons, months related both to the Jewish lunar-solar and to the Julian calendars, moon phases. No date, however, is stated explicitly with respect to the Julian calendar, except for a single case (Matricciani and De Caro 2017), but with no reference to the year. Nevertheless, from her writings it is possible to determine univocally the date of Jesus' crucifixion.

Her narration of Jesus' life explicitly states (Valtorta 2001d) that in the year before his death the Passover (Nisan 15) fell on Saturday. Therefore, in that year Nisan 14 was a Friday. 
According to the Gospels, the crucifixion day was also a Friday. With reference to the possible dates of crucifixion listed in Table 6, the occurrence of two consecutive Fridays just before Passover (Saturday) is an extremely binding constraint. Only in the years 33 and 34 this occurred - highlighted in red in Table 6-, because Passover on 27 April 31 must be excluded as discussed above. Therefore, the year of crucifixion logically deducible from MV's writings is 23 April 34. The analysis here described allows to conclude that the unusual indication of two consecutive Passovers on Saturday, the year before Jesus' death and the year of his death, which we find in the MV literary work, is a chronological constraint so strong that it could have had no solution at all.

It is interesting also to note that this date - first calculated by Isaac Newtown and only recently re-proposed (La Greca and De Caro 2017) -, today is hardly considered by scholars, although it seems more probable than other dates, just because it allows to harmonize the Synoptic and Johannine traditions about the Last Supper, as discussed in the previous section. Therefore, we must exclude that MV narrated Jesus' life by deliberately assuming this Crucifixion date and consequently inserting suitable calendar elements to link her story of Jesus' Passion just to 23 April 34. Indeed, even admitting that all this was within her knowledge - which was not -, realistically she would have chosen the Crucifixion date considered by scholars of her time, as we recall below.

From $1 \mathrm{AD}$ to $34 \mathrm{AD}$ there were 7 leap years: 8, 12, 16, 20, 24, 28, 32 (see Section 2). Now, from January 6 to April 23, there are 107 days which added to $33 \times 365+7=12052$ days give 12159 days. Now 12159/7 = 1737 weeks, exactly Jesus' life duration according to MV (Valtorta 1993), an unexpected coincidence deserving more attention.

This integer number could be the result of a calculation she made and passed off as a mystical revelation. If this were the case, however, we would expect a calculation starting on 25 December 1 BC, Western Nativity Day, and ending on 3 April 33, day of crucifixion according to the Catholic Church who had just celebrated on 3 April 1933 the anniversary of Jesus' death, 1900 years, an event she knew (Valtorta 2006). These dates do not give 1737 weeks. Curiously, her alleged mystical experiences began on Good Friday 23 April 1943 
(Matricciani et al 2017), an "anniversary" of Jesus' crucifixion if set on Friday 23 April 34. The coincidence is striking because it is rare that Good Friday coincides with 23 April: the last time it was in 1886 and the next time it will be in 2038 .

Another surprising result is the following. Several times she writes that Jesus was born on 25 Kislev, which is first day of the Feast of Temple Dedication, but never writes a Julian date, neither December 25 nor January 6, nor a year, either for birth or for Crucifixion. However, the beginning of the Feast of Temple Dedication, associated with a life lasting 1737 weeks, leads once again to the Eastern tradition of 6 January 1 AD for the Nativity Day and to Crucifixion on 23 April 34.

Moreover, let us note that $70 \%$ of all gestations leads to birth after $38 \pm 1$ weeks from conception (Chow et al 2009). If $38 \pm 1$ weeks are added to 1737 weeks, we get $1775 \pm 1$ weeks from Jesus' conception to death which, converted in years, correspond to the interval (34 years +1 week) \pm 1 week. In other words, if Jesus was really born on Kislev 25 (about 6 January 1 AD), then from conception to death at Passover (23 April 34) there are almost exactly an integer number of years, within a maximum difference of just 1 or 2 weeks. Thus, his conception should be set, with a probability of 70\% (Chow et al 2009), $1 \pm 1$ weeks before April 23, date of his death, i.e., in the interval 9 April to 23 April 1 BC. From Table 1 we note that the year's eve of $1 \mathrm{BC}$ (embolismic) is just 23 April, confirming, surprisingly, what the Star-of-Bethlehem's message indicated: Jesus' conception just at the end of the lunisolar year.

\section{Conclusion}

We have investigated the possibility of a coherent chronological background in the MV's literary work about Jesus' life. We have started our research by assuming that Jesus was born on $25 \mathrm{Kislev}$, as MV stated in her writings. Now, to verify whether $25 \mathrm{Kislev}$ coincides with 25 December $1 \mathrm{BC}$ or 6 January $1 \mathrm{AD}$, we have converted dates from the luni-solar calendar to the Julian calendar. This conversion, not straight, has required addressing several 
arguments such as the presence of embolismic years in the luni-solar calendar and leap years in the Julian calendar, the beginning of months in the luni-solar calendar, the beginning of the Feast of Temple Dedication (i.e., 25 Kislev) in the Julian calendar. We have investigated these topics and our investigation indicates a preference for 6 January $1 \mathrm{AD}$ as the day of birth, because it correlates very well with Kislev 25, with the year of Crucifixion 34 AD, hardly considered by scholars, and the age of Jesus (about 33 years) when he died. In particular, the analysis presented in this study shows that, unlike the years 30 and 33 - possible alternatives for the year of the Crucifixion hypothesized by scholars- the year 34 is the only one that allows to harmonize chronologically the Synoptic and Johannine traditions on the Last Supper and the Crucifixion.

Secondly, we have researched in the Gospels the historical background of the traditional Nativity Day at the beginning of the winter. According to Luke, Elizabeth was pregnant in the sixth month at the time of the Annunciation to Mary. Because in a year three pilgrimages to Jerusalem were required - namely at Passover, at Pentecost and the Tabernacles- we have shown that the Annunciation occurred in the year $1 \mathrm{BC}$, after about 6 months since the Tabernacles of $2 \mathrm{BC}$, therefore, just before the Passover of $1 \mathrm{BC}$, because Mary was not aware of the sixth month's pregnancy of Elizabeth, therefore implying that Joseph had not gone on pilgrimage to Jerusalem in the last six months. Consequently, after 9 months, the Nativity Day should have occurred at the beginning of winter, just as indicated in the West and East traditions and in the MV's literary work.

Thirdly, as verified in Section 8, the hypothesis of the early Christian chronographers about an integer number of years from conception to crucifixion of Jesus, i.e. same month and day for conception and death, could be not only a mere speculation, but it could have an historical foundation, if the Nativity Day is set just on Kislev 25 and his death at Passover (Nisan 15), or at Passover Eve (Nisan 14), as reported by the Gospels. Indeed, from the beginning of the winter (Feast of Temple Dedication) to the beginning of spring (Passover) there are about 3 months which, added to 9 months of a pregnancy, give a full year. We obtain exactly 34 years with an error in excess ranging from 0 to 2 week (see Section 8 ). 
Fourthly, we have researched the Star of Bethlehem on which there is a vast literature since the beginning of Christianity. Most ancient commentators rejected the hypothesis of a natural phenomenon in favor of a divine intervention. Others affirmed that it was a natural phenomenon.

MV writes it was a miracle but, in her writings, we find some very interesting information about a possible way of decoding a series of astronomical conjunctions done by the Magi astronomers and scientists before the modern development of astronomy and science in general - for knowing about the birth of the king of Jews. We astronomically checked this novel hypothesis about the Star of Bethlehem, found, in our knowledge, only in MV writings, by considering the cultural framework of Magi, deducing chronological data associated to the birth of the Messiah.

We have supposed the Magi considered some conjunctions Jupiter-Venus and Venus-Regulus occurred just before and after the rare conjunction Jupiter-Venus on 17 June $2 \mathrm{BC}$, when the two planets were indistinguishable at naked eyes, and three consecutive conjunctions of Jupiter with Regulus. Then, going back with respect to 17 June 2 BC, they supposedly chose one of these conjunctions as reference date for counting the time elapsed, in days, between other conjunctions. To these intervals they assigned a meaning through Gematria. In other words, we have tried to think and act as they supposedly did to interpret the time series of the astronomical conjunctions with the knowledge and methods of 2000 years ago, mainly by means of the Gematria, a coding/decoding technique widespread in the Middle East and, more generally, in the Greek-Roman world. We were surprised and struck in finding a tight relationship between the Gematria-mediated decoding of the considered astronomical conjunctions with some key information about the Star of Bethlehem, written in Italian by MV.

Ultimately, MV's literary works about Jesus's life, seems to have a coherent chronological background, also underlying the narration of the Magi and the Star of Bethlehem. Indeed, MV never indicates the year of Jesus' birth or crucifixion, even if she reports chronological information like days of worship rest, references to major Jewish holy days, market days, 
seasons, months related both to the Jewish lunar-solar and to the Julian calendars. Nevertheless, after a scientific analysis of her writings, discussed in this paper, it is possible: i) to determine univocally the date of Jesus' crucifixion, 23 April 34; ii) to relate his birth's date, on Kislev 25, to the Eastern tradition of January 6 for Nativity in 1 AD, at the beginning of Christina Era, as calculated by Dionysius Exiguus; iii) to verify as exact the indication of 1737 weeks of his life. As different pieces of the same puzzle, all these chronological elements combine perfectly, showing as the MV's narration of Jesus' life contains a welldefined and coherent chronological framework. The verification of the origin of this hidden information is beyond the scope of our work. Future works could answer the question if the consistence of the chronological framework, underlying MV's narration of Jesus' life, is verified at a daily time scale, since The Gospels as revealed to me (Valtorta 2001e) describes day by day Jesus' public life, but without writing explicitly any Julian calendar's date, in terms of day, month and year.

\section{Appendix A. Probability calculations}

Let us calculate the total number of independent selections that can be done from a number of items in $k$ sets (or rows) in which there are, at each step, $n_{i}$ items with $i=1$ to $k$. Let $n_{1}$ be the number of the first set of items and $n_{2}$ the number of the second set. There are $n_{1} \times n_{2}$ equally probable connections linking each item of the first set (row) to each item of the second set (row), therefore this is also the total number of equiprobable series allowed. If another set (row), with $n_{3}$ items, follows, then there are $n_{2} \times n_{3}$ new series to add to the previous series, and so on. Therefore, the number $N_{k}$ of independent and equiprobable series obtainable after $k$ sets (rows) is given by:

$$
N_{k}=n_{1} \times n_{2}+n_{2} \times n_{3}+n_{3} \times n_{4}+\ldots+n_{k-1} \times n_{k}
$$

Therefore, the probability of a particular series of items selected is:

$$
p_{k}=1 / N_{k}
$$

In Table 5 there are $N_{k}=2558$ possible connections, therefore, $p_{k}=1 / 2558=0.04 \%$. 


\section{References}

[1] (Adair 2012) Adair, Aaron. 2012. The star of Christ in the light of Astronomy. Zygon 47: $7-29$.

[2] (Allison 1993) Allison, Dale C. Jr. 1993. What Was the Star That Guided the Magi?. Bible Review 9: 20-24.

[3] (Barthel et al 2015) Barthel, Peter, and George van Kooten (Eds.). 2015. The Star of Bethlehem and the Magi. Interdisciplinary Perspectives from Experts on the Ancient Near East, the Greco-Roman World, and Modern Astronomy. Leiden-Boston: Brill.

[4] (Bond 2013) Bond, Helen K. 2013. Dating the Death of Jesus: Memory and the Religious Imagination. New Testament Studies 59: 461-475.

[5] (Brown 1999) Brown, Raymond E. 1999. The birth of the Messiah. Yale: Yale University Press.

[6] (Bryan 2020) Bryan, Steven M. 2020. Onomastics and Numerical Composition in the Genealogy of Matthew, Bulletin for Biblical Research 30: 4, 515-539.

[7] (Chow et al 2009) Chow, Yuan H. and Dattani, Nirupa. 2009. Estimating conception statistics using gestational age information from NHS numbers for Babies data, Health Statistics Quaterly 41, pp. 21-27.

[8] (Carrol et al 2007) Carrol, Bradley and Ostlie, Dale. 2007. An Introduction to Modern Astrophysics. San Francisco, USA: Addison-Wesley.

[9] (Chevalley 2006) Chevalley, Patrick. 2006. Astronomic software Skychart, https://www.ap-i.net/skychart/en/start.

[10] (Clark et al 1977) Clark, David H. and F. Richard Stephenson. 1977. The Historical Supernovae, Oxford: Pergamon Press.

[11] (Cullen 1979) Cullen, Christopher. 1979. Can we Find the Star of Bethlehem in Far Eastern records?. Quarterly Journal of the Royal Astronomical Society 20: 153-159.

[12] (Davis 1968) Davis, John James. 1968. Biblical Numerology. Grand Rapids, MI: Baker Books House. 
[13] (De Caro et al 2020) De Caro, Liberato, Fernando La Greca and Emilio Matricciani. 2020. Saint Peter's First Burial Site According to Maria Valtorta's Mystical Writings, Checked Against the Archeology of Rome in the I Century, J Multidisciplinary Scientific Journal 3: $366-400$.

[14] (De Caro et al 2021a) De Caro, Liberato, Fernando La Greca and Emilio Matricciani. 2021. The search of St Peter's memory ad catacumbas in the cemeterial area ad Duos Lauros in Rome, Heritage 4: 479-506.

[15] (De Caro et al. 2021b) De Caro, Liberato, Fernando La Greca and Emilio Matricciani. 2021. The Beginning of the Christian Era Revisited: New Findings. Histories 1, 145-168.

[16] (Derovan 2007) Derovan, David. 2007. "Gematria", in Skolnik, Fred (Editor in Chief) and Michael Berembaum (Executive Editor), Encyclopaedia Judaica, $2^{\text {nd }}$ ed., vol. 7, FeyGor. Detroit (USA): Thomson Gale; p. 424.

[17] (Di Maio et al 1988) Di Maio, Michael, Jorn Zeuge and Natalia Zotov. 1988. Ambiguitats Constantiniana: The Caeleste Signum of Constantine The Great. Byzantion 58: 2, $333-360$.

[18] (Doggett et al. 1994) Doggett, LeRoy E. and Bradley E. Schaefer. 1994. Lunar Crescent Visibility. Icarus 107: 388-403.

[19] (Duchesne 1889) Duchesne, Louis. 1889. Origines du culte chrétien: étude sur la liturgie latine avant Charlemagne. Paris: Thorin; pp. 247-54.

[20] (Engberding 1952) Engberding, Hieronymus. 1952. Der 25. Dezember als Tag der Feier der Geburt des Herrn. Archiv für Liturgiewissenschaft 2: 25-43.

[21] (Epping 1889) Epping, Joseph. 1889. Astronomisches aus Babylon oder das Wissen der Chaldaer uber den gestirnten Himmel. Freiburg: Herder.

[22] (Farrar 1961) Farrar, F. W. 1961. Hystory of Interpretation, Grand Rapids: Baker, p. 168.

[23] (Fatoohi et al 1997-1998) Fatoohi, L.J. and Stephenson, F.R. 1997/1998. Angular measurements in Babylonian astronomy. Archiv für Orientforschung 44/45: 210-214.

[24] (Fedalto 2012) Fedalto, Giorgio. 2012. Da Pasqua il tempo nuovo. Questioni di cronologia ebraico-cristiana. Verona: Mazziana; pp. 53-71. 
[25] (Finegan 1998) Finegan, Jack. 1998. Handbook of Biblical Chronology. Principles of Time Reckoning in the Ancient World and Problems of Chronology in the Bible. Revised Edition. Peabody: Hendrickson Publishers; pp. 269-368.

[26] (Firpo 1983) Firpo, Giulio. 1983. Il problema cronologico della nascita di Gesù, Brescia: Paideia Editrice.

[27] (Fotheringham 1934) Fotheringham, John Knight. 1934. The Evidence of Astronomy and Technical Chronology for the Date of the Crucifixion. Journal of Theological Studies 35: $146-62$.

[28] (Heidrick 2021) Heidrick, Bill. Website: http://www.billheidrick.com/works/hgemat.htm, web site accessed 17 June 2021.

[29] (Hohenkerk et al 1992) Hohenkerk, C. Y., B. D. Yallop, C. A. Smith and A. T. Sinclair. 1992. Celestial Reference Systems. In Explanatory Supplement to the Astronomical Almanac. Edited by P. Kenneth Seidelmann. Sausalito (CA): University Science Books; p. 99.

[30] (Holzmeister 1942) Holzmeister, Urban. 1942. La stella dei Magi. Civiltà Cattolica 9: $9-22$.

[31] (Hughes 1976) Hughes, David W. 1976. The Star of Bethlehem. Nature 264: 513-517.

[32] (Hughes 1979) Hughes, David W. 1979. The Star of Bethlehem. An Astronomer's Confirmation, New York: Walker.

[33] (Humphreys et al 1983) Humphreys, Colin J. and W. Graeme Waddington. 1983. Dating the Crucifixion. Nature 306: 743-746.

[34] (Humphreys et al 1992) Humphreys, Colin J. and W. Graeme Waddington. 1992. The Jewish Calendar, a Lunar Eclipse and the Date of Christ's Crucifixion. Tyndale Bulletin 43: $331-351$.

[35] (Hunger et al 1988-1996) Hunger, Hermann and Abraham J. Sachs. 1988-1996. Astronomical Diaries and Related Texts from Babylonia, voll. I-III, H. Hunger Ed., Wien: Verlag der Österreichische Akademie der Wissenschaften.

[36] (Hunger et al 2001) Hunger, Hermann, Abraham J. Sachs and John M. Steele. 2001. 
Astronomical diaries and related texts from Babylonia. Lunar and Planetary Texts. Vol. V. Wien: Verlag der Österreichische Akademie der Wissenschaften.

[37] (Ian 2018) Ian, Paul. 2018. Revelation: an Introduction and Commentary. (Tyndale New Testament Commentaries). Downers Grove: InterVarsity Press.

[38] (Jastrow 1908) Jastrow, Morris. 1908. Hepatoscopy and Astrology in Babylonian and Assyria, Proceedings of the American Philosophical Society 47: 646-676.

[39] (Kennedy et al 1971) Kennedy E. S. and David Pingree. 1971. The Astrological History of Masha'allah. Cambridge, MA: Harvard University Press.

[40] (Kepler 1614) Kepler, Johannes. 1614. De anno natali Christi. (= De vero anno quo Aeternus Dei Filius humanam naturam in utero benedictae Virginis Mariae assumpsit). In Gesammelte Werke. Chronologische Schriften. München: C. H. Beck'sche Verlagsbuchhandlung, 1953. Vol. V, pp. 5-126.

[41] (Kraabel 1982) Kraabel, A. Thomas. 1982. The Roots of Christmas. Dialog 21: 274-280.

[42] (La Greca and De Caro 2017) La Greca, Fernando, and Liberato De Caro. 2017. Nuovi studi sulla datazione della crocifissione nell'anno 34 e della nascita di Gesù il 25 dicembre dell'1 a.C. Annales Theologici 31: 11-52.

[43] (La Greca and De Caro 2019) La Greca, Fernando, and Liberato De Caro. 2019. La datazione della morte di Erode e l'inizio dell'era cristiana. Annales Theologici 33: 11-54.

[44] (La Greca and De Caro 2020) La Greca, Fernando, and Liberato De Caro. 2020. Approfondimenti sulla nascita di Gesù nell'1 1 a.C. e sulla datazione della Crocifissione nel 34. Annales Theologici 34: 13-58.

[45] (Leeming et al 2003) Leeming, Henry, and Kate Leeming. 2003. Josephus' Jewish War and its Slavonic Version - A Synoptic Comparison, Leiden-Boston: Brill.

[46] (Léna 1996) Léna, P. 1996. Un fenomeno celeste? Il mondo della Bibbia 7: 16-17.

[47] (Lichtenstein 1913) Lichtenstein, Jechiel. 1913. Kommentar zum Matthäus-Evangelium (hebr.). Leipzig. 
[48] (Lieberman 1987) Lieberman, Stephen, J. 1987. A Mesopotamian Background for the socalled Aggadic 'Measures' of biblical hermeneutics?, Hebrew Union College Annual 58, pp. $157-225$.

[49] (Marchant 2009) Marchant, Jo. 2009. Decoding the Heavens, Windmill Books, London, UK.

[50] (Martin 1998) Martin, Ernest L. 1998. The Star that Astonished the World. Portland: ASK Publications.

[51] (Martindale 1909) Martindale, I. Cyril. 1909. Epiphany. In The Catholic Encyclopedia. New York: Robert Appleton Company.

[52] (Matricciani 2019) Matricciani, E. 2019. Deep Language Statistics of Italian throughout Seven Centuries of Literature and Empirical Connections with Miller's $7 \mp 2$ Law and Short-Term Memory. Open Journal of Statistics, 9, 373-406. doi: $\underline{10.4236 / 0 j s .2019 .93026}$.

[53] (Matricciani and De Caro 2017) Matricciani, Emilio, and Liberato De Caro. 2017. Literary Fiction or Ancient Astronomical and Meteorological Observations in the Work of Maria Valtorta?, Religions 8: 110, 1-23.

[54] (Matricciani and De Caro 2018) Matricciani, Emilio, and Liberato De Caro. 2018. A Mathematical Analysis of Maria Valtorta's Mystical Writings. Religions 9: 373, 1-23.

[55] (Matricciani and De Caro 2020) Matricciani, Emilio, and Liberato De Caro. 2020. Jesus Christ's Speeches in Maria Valtorta's Mystical Writings: Setting, Topics, Duration and Deep-Language Mathematical Analysis. J Multidisciplinary Scientific Journal 3: $100-123$.

[56] (Méhat 1966) Méhat, A. 1966. Etude sur les 'Stromates' de Clément d'Alexandrie, Patristica Sorbonensia, 7, Paris: du Seuil, p. 202.

[57] (Michalski 2021) Michalski, Mateusz. 2021. Tikkun Chatzot - semiotics of synagogues on the example of the synagogue in Siemiatycze. Architectus 65: 3-10.

[58] (Molnar 1999) Molnar, Michael R. 1999. The Star of Bethlehem: The Legacy of the Magi, London: Rutgers University Press. 
[59] (Mosley 1981) Mosley, John D. 1981. Common errors in "Star of Bethlehem" planetarium shows. The Planetarian 10: 4-7.

[60] (Neugebauer 1955) Neugebauer, Otto. 1955. Astronomical cuneiform texts, vol. 3. London: Institute for Advanced Study.

[61] (Nodet 2011) Nodet, Étienne. 2011. Pharisees, Sadducees, Essenes, Herodians. In Handbook for the Study of the Historical Jesus (4 vols). Edited by Tom Holmén and Stanley E. Porter. Leiden-Boston: Brill, pp. 1525-1543.

[62] (Nothaf 2012a) Nothaf, C. Philipp E. 2012. The Origins of the Christmas Date: Some Recent Trends in Historical Research. Church History 81: 903-911.

[63] (Nothaf 2012b) Nothaf, C. Philipp E. 2012. Dating the Passion. The Life of Jesus and the Emergence of Scientific Chronology (200-1600). Leiden-Boston: Brill.

[64] (Paffenroth 1993) Paffenroth, Kim. 1993. The Star of Bethlehem Casts Light on its Modern Interpreters. Quarterly Journal of the Royal Astronomical Society 34: 449-460.

[65] (Panaino 2012) Panaino, A. 2012. I magi e la loro stella, Milano: San Paolo Ed.

[66] (Parker et al 1956) Parker, Richard A. and Waldo H. Dubberstein. 1956. Babylonian Chronology 620 B.C. - A.D. 75. Providence: Brown University Press.

[67] (Pedersen 1983) Pedersen, Olaf. 1983. The Ecclesiastical Calendar and the Life of the Church. In Gregorian Reform of the Calendar, edited by George V. Coyne, Michael A. Hoskin, and Olaf Pedersen. Vatican City: Pontificia Academia Scientiarium; pp. 17-74. [68] (Pratt 1990) Pratt, John P. 1990. Yet another Eclipse for Herod. The Planetarian 19: 8-14. [69] (Quéré 1996) Quéré, F. 1996. I magi alla luce della stella. Il mondo della Bibbia 7: 12-15. [70] (Roll 1995) Roll, Susan K. 1995. Toward the Origins of Christmas. Kampen (NL): Kok Pharos.

[71] (Ruggles 1990) Ruggles, Clive. 1990. The Moon and the Crucifiction. Nature 345: 669-670.

[72] (Schaefer 1990) Schaefer, Bradley E. 1990. Lunar Visibility and the Crucifixion. Quarterly Journal of the Royal Astronomical Society 31: 53-67. 
[73] (Sinnot 1968) Sinnott, Roger W. 1968. Thoughts on the Star of Bethlehem. Sky $\mathcal{E}$ Telescope 36: 384-386.

[74] (Strack et al 1924) Strack, Hermann L., and Paul Billerbeck. 1924. Kommentar zum Neuen Testament aus Talmud und Midrasch. Zweiter Band. Das Evangelium nach Markus, Lukas und Johannes und die Apostelgeschichte. München: Beck, p. 812-853.

[75] (Strobel 1977) Strobel, August. 1977. Ursprung und Geschichte des frühchristlichen Osterkalenders. Berlin: Akademie Verlag.

[76] (Talley 1991) Talley, Thomas Julian. 1991. The Origins of the Liturgical Year. $2^{\text {nd }}$ ed., Collegeville, MI: Pueblo, pp. 79-155.

[77] (Talley 2003) Talley, Thomas Julian. 2003. Afterthoughts on The Origins of the Liturgical Year. In Western Plainchant in the First Millennium: Studies in the Medieval Liturgy and Its Music, Edited by Sean Gallagher et al., Aldershot, U.K.: Ashgate, pp. 110.

[78] (Teres 2000) Teres, Gustav. 2000. The Bible and Astronomy. The Magi and the Star in the Gospel. Budapest: Springer.

[79] (Valtorta 1993) Valtorta, Maria. 1993. The Book of Azariah. Isola del Liri (Fr): Centro Editoriale Valtortiano, p. 64.

[80] (Valtorta 2001a) Valtorta, Maria. 2001. The Gospel as revealed to me. Vol. I, Isola del Liri (Fr): Centro Editoriale Valtortiano.

[81] (Valtorta 2001b) Valtorta, Maria. 2001. The Gospel as revealed to me. Vol. II, Isola del Liri (Fr): Centro Editoriale Valtortiano, p. 375.

[82] (Valtorta 2001c) Valtorta, Maria. 2001. L'Evangelo come mi è stato rivelato. Vol. I. Isola del Liri (Fr): Centro Editoriale Valtortiano, p. 204.

[83] (Valtorta 2001d) Valtorta, Maria. 2001. The Gospel as revealed to me. Vol. VI. Isola del Liri (Fr): Centro Editoriale Valtortiano, p. 143.

[84] (Valtorta 2001e) Valtorta, Maria. 2001. The Gospel as revealed to me. Voll. I-X, Isola del Liri (Fr): Centro Editoriale Valtortiano.

[85] (Valtorta 2006) Valtorta, Maria. 2006. Quaderni del 1945-1950. Isola del Liri (Fr): 
Centro Editoriale Valtortiano, p. 394.

[86] (Wright et al 2002) Wright, Addison G., Roland E. Murphy and Joseph A. Fitzmyer. 2002. Una storia di Israele. In Nuovo Grande Commentario Biblico, a cura di Raymond E. Brown, Joseph A. Fitzmyer, Roland E. Murphy. Brescia: Queriniana, pp. 1605-1641. 